\title{
Spectroscopic characterization of the oxo-transfer reaction from a bis( $\mu$-oxo)dicopper(III) complex to triphenylphosphine $\dagger$
}

\author{
Svetlana V. Pavlova, ${ }^{a}$ Kelvin H.-C. Chen ${ }^{a, b}$ and Sunney I. Chan ${ }^{\star a, b}$ \\ a Institute of Chemistry, Academia Sinica, Taipei 115, Taiwan. \\ E-mail: chans@chem.sinica.edu.tw; Fax: +886-2-2783-1237; Tel: +886-2-2783-1237 \\ ${ }^{b}$ Department of Chemistry, National Tsing Hua University, Hsinchu, 300, Taiwan
}

Received 4th May 2004, Accepted 17th August 2004

First published as an Advance Article on the web 31st August 2004

The oxygen-atom transfer reaction from the bis( $\mu$-oxo)dicopper(III) complex $\left[\mathrm{Cu}^{\mathrm{III}}{ }_{2}(\mu-\mathrm{O})_{2}(\mathrm{~L})_{2}\right]^{2+} \mathbf{1}$, where $\mathrm{L}=N, N, N^{\prime}, N^{\prime}$-tetraethylethylenediamine, to $\mathrm{PPh}_{3}$ has been studied by $\mathrm{UV}$-vis, EPR, ${ }^{1} \mathrm{H}$ NMR and Cu K-edge X-ray absorption spectroscopy in parallel at low temperatures $(193 \mathrm{~K})$ and above. Under aerobic conditions (excess dioxygen), 1 reacted with $\mathrm{PPh}_{3}$, giving $\mathrm{O}=\mathrm{PPh}_{3}$ and a diamagnetic species that has been assigned to an oxo-bridged dicopper(II) complex on the basis of EPR and $\mathrm{Cu} \mathrm{K}$-edge X-ray absorption spectroscopic data. Isotope-labeling experiments $\left({ }^{18} \mathrm{O}_{2}\right)$ established that the oxygen atom incorporated into the triphenylphosphine oxide came from both complex 1 and exogenous dioxygen. Detailed kinetic studies revealed that the process is a third-order reaction; the rate law is first order in both complex 1 and triphenylphosphine, as well as in dioxygen. At temperatures above $233 \mathrm{~K}$, reaction of 1 with $\mathrm{PPh}_{3}$ was accompanied by ligand degradation, leading to oxidative $\mathrm{N}$-dealkylation of one of the ethyl groups. By contrast, when the reaction was performed in the absence of excess dioxygen, negligible substrate $\left(\mathrm{PPh}_{3}\right)$ oxidation was observed. Instead, highly symmetrical copper complexes with a characteristic isotropic EPR signal at $g=2.11$ were formed. These results are discussed in terms of parallel reaction channels that are activated under various conditions of temperature and dioxygen.

\section{Introduction}

Copper ions are found in the active sites of many redox-active metalloproteins involved in important biological electron and oxygen transfer reactions. ${ }^{1-3}$ During recent years much effort has been directed toward modeling the reactions of copper enzymes with dioxygen in order to elucidate the mechanism of dioxygen activation by copper monooxygenases as well as to develop efficient catalytic systems for selective oxidation of organic substrates by dioxygen. ${ }^{4-9}$ In this regard, the series of copperdioxygen complexes, such as $\left(\mu-\eta^{2}: \eta^{2}\right.$-peroxo)dicopper(II) and bis( $\mu$-oxo)dicopper(III), have been most extensively studied since these binuclear metal sites have been proposed as models of reactive intermediate(s) at the active sites of copper monooxygenases..$^{3-6,8-12}$ Understanding how synthetic model systems and copper proteins utilize dioxygen to oxidize substrates is a timely and important research topic.

Several examples of intermolecular oxygen-atom transfer reactions mediated by copper-dioxygen species with the $\mathrm{Cu}_{2} \mathrm{O}_{2}$ core are described in the literature. ${ }^{13-20}$ Mahadevan et al. ${ }^{14}$ have studied the oxidation of triphenylphosphine $\left(\mathrm{PPh}_{3}\right)$ with $\mathrm{Cu}_{2} \mathrm{O}_{2}$ complexes supported by $N, N^{\prime}$-di-tert-butyl- $N, N^{\prime}$-dimethyl-1,2ethanediamine under conditions of slow equilibrium between the bis( $\mu$-oxo $)$ and side-on peroxo isomers in 2-methyltetrahydrofuran, and demonstrated that the $\left(\mu-\eta^{2}: \eta^{2}\right.$-peroxo)dicopper(II) appears to be the better oxygen-atom transfer reagent compared to its bis( $\mu$-oxo)dicopper(III) counterpart. An exception was noted for the bis( $\mu$-oxo) complex supported by $N, N, N^{\prime}, N^{\prime}$ tetramethylpropanediamine, which quantitatively converts $\mathrm{PPh}_{3}$ into triphenylphosphine oxide $\left(\mathrm{O}=\mathrm{PPh}_{3}\right){ }^{13}$ These authors have suggested that accessibility of the substrate $\left(\mathrm{PPh}_{3}\right)$ to the $\mathrm{Cu}_{2} \mathrm{O}_{2}$ core is an important factor that governs the observed difference in reactivity. ${ }^{14}$ Irrespective of whether the bis $(\mu$ oxo) or side-on peroxo isomer, supported by peralkylated

$\uparrow$ Electronic supplementary information (ESI) available: Plots of the pseudo-first-order rate constant $k_{\text {obs }}$ obtained from analysis of initial rates as a function of $\left[\mathrm{PPh}_{3}\right]_{0}$ (Fig. S1) or $\left[\mathrm{O}_{2}\right]_{0}$ (Fig. S2) for the reaction of 1 with $\mathrm{PPh}_{3}$. Fig. S3: Kinetic traces of the absorbance change at $404 \mathrm{~nm}$ during the reaction of 1 with $\mathrm{PPh}_{3}$ under dioxygen in the absence and presence of $\mathrm{O}=\mathrm{PPh}_{3}$. See http://www.rsc.org/suppdata/dt/ b4/b406692h/ diamines ligands, mediates the oxygen-atom transfer directly, the oxidation of $\mathrm{PPh}_{3}$ is facile under a dioxygen atmosphere. ${ }^{13-15}$ In the case of the bis( $\mu$-oxo)dicopper(III) species capped with the aromatic $\mathrm{N}$-donor ligand $\mathrm{Me}_{2}$ tpa, the reaction with $\mathrm{PPh}_{3}$ at $195 \mathrm{~K}$ under Ar causes the stoichiometric displacement of bound $\mathrm{O}_{2}$, producing the $\left[\mathrm{Cu}\left(\mathrm{Me}_{2} \mathrm{tpa}\right)\left(\mathrm{PPh}_{3}\right)\right]^{+}$complex. ${ }^{17} \mathrm{By}$ contrast, it was recently reported ${ }^{18}$ that sulfoxidation reactions mediated by the bis( $\mu$-oxo)dicopper(III) complex supported by the ligand $\mathrm{L}^{\mathrm{Py} 1 \mathrm{Bz}}$ proceeded under anaerobic conditions via a direct oxygen-atom transfer mechanism involving formation of a binary complex between the substrate and the metal oxospecies. Oxidation of the amine moiety of the supporting ligand to the corresponding $N$-oxide by $\left(\mu-\eta^{2}: \eta^{2}\right.$-peroxo)dicopper(II) complex has also been reported. ${ }^{19}$ It was suggested that the oxotransfer reaction here is effected by a very reactive intermediate derived from $\left(\mu-\eta^{2}: \eta^{2}\right.$-peroxo)dicopper(II) which was formed in the steady-state. Recently, the facile oxidation of a variety of exogenous substrates mediated by $\left(\mu-\eta^{2}: \eta^{2}\right.$-peroxo)dicopper(II) isomers with $\mathrm{R}-\mathrm{MePY}_{2}$ ligands has also been reported. ${ }^{20}$

We report here parallel EPR, ${ }^{1} \mathrm{H}$ NMR and Cu K-edge X-ray absorption spectroscopic and UV-vis kinetic studies of the chemistry between a bis( $\mu$-oxo)dicopper(III) complex and $\mathrm{PPh}_{3}$ under various conditions in order to derive more information on the process of oxygen-atom transfer from the bis $\left[\mathrm{Cu}_{2}(\mu-\right.$ $\left.\mathrm{O})_{2}\right]^{2+}$ core to exogenous substrates. Toward this end, we have deployed various spectroscopic methods to characterize the chemical species formed during the putative oxo-transfer reaction, and to elucidate the role of exogenous dioxygen. In addition, we have resorted to kinetic studies in order to elucidate the role of the various reactants in the overall reaction mechanistic scheme. Specifically, we have focused on the known complex, ${ }^{21}$ $\left[\mathrm{Cu}^{\mathrm{III}}{ }_{2}(\mu-\mathrm{O})_{2}(\mathrm{~L})_{2}\right]^{2+} \mathbf{1}$, supported by $N, N, N^{\prime}, N^{\prime}$-tetraethylethylenediamine $(\mathrm{L})$, which is relatively stable at low temperatures, to probe the details of the reaction(s) with $\mathrm{PPh}_{3}$.

\section{Results and discussion}

Preparation and spectroscopic characterization of $\left[\mathrm{Cu}^{\mathrm{III}}{ }_{2}(\mu-\right.$ $\left.\mathrm{O})_{2}(\mathrm{~L})_{2}\right](\mathrm{X})_{2}\left(\mathrm{X}=\mathrm{ClO}_{4}^{-}, \mathrm{BF}_{4}^{-}\right)(1)$

Bis( $\mu$-oxo)dicopper(III) complex 1, was prepared in situ by treating $[\mathrm{LCu}(\mathrm{MeCN})] \mathrm{BF}_{4}$ or $[\mathrm{LCu}(\mathrm{PhCN})] \mathrm{ClO}_{4}$ with dioxygen 
in anhydrous dichloromethane at $193 \mathrm{~K}$, according to the published procedure ${ }^{14}$ (Scheme 1). Spectroscopic characterization of 1 was performed in $\mathrm{CH}_{2} \mathrm{Cl}_{2}$ at $193 \mathrm{~K}$. Optical absorption spectroscopy showed the characteristic intense LMCT bands at $\lambda_{\max }=307$ and $404 \mathrm{~nm}$. EPR of a frozen solution of 1 was silent at $77 \mathrm{~K}$. The $\mathrm{Cu} \mathrm{K}$-edge absorption spectrum of 1 exhibited a pre-edge feature at $8981.1 \mathrm{eV}$, corresponding to the $1 \mathrm{~s} \rightarrow 3 \mathrm{~d}$ transition characteristic of $\mathrm{Cu}(\mathrm{III})$ compounds. ${ }^{21}$ These spectroscopic data indicated that the oxygenated solution of the starting $\mathrm{Cu}(\mathrm{I})$ precursor is the bis( $\mu$-oxo)dicopper(III) complex, in good agreement with the results reported previously by Stack et al. ${ }^{21-23}$

$$
2[\mathrm{LCu}(\mathrm{PhCN})]^{+} \stackrel{\mathrm{O}_{2}}{\longrightarrow} \mathrm{LCu}_{\mathrm{O}}^{\mathrm{II \prime}} \mathrm{Cu}^{\mathrm{O} I \mathrm{~L}} \mathrm{I}^{2+}
$$

Scheme 1

In addition to the spectral data of $\mathbf{1}$ reported previously, we have monitored the formation of 1 by ${ }^{1} \mathrm{H}$ NMR spectroscopy at low temperature $(193 \mathrm{~K})$. The spectrum of $\left[\mathrm{Cu}^{\mathrm{III}}{ }_{2}(\mu-\mathrm{O})_{2}(\mathrm{~L})_{2}\right]^{2+}$ is quite simple. Chemical shifts for $\mathbf{1}$ at $1.40 \mathrm{ppm}$ and 2.99 $3.28 \mathrm{ppm}$ are downfield shifted from the corresponding values in the case of the starting $\mathrm{Cu}$ (I) complex (see Experimental section). The lack of extensive broadening of the ${ }^{1} \mathrm{H}$ NMR resonances for the copper(III) species and the presence of relatively sharp peaks with chemical shifts in the normal region $(0-10 \mathrm{ppm})$ is consistent with the diamagnetic behavior of $\mathbf{1}$. Under slow oxygenation of a solution of the $\mathrm{Cu}(\mathrm{I})$ complex in $\mathrm{CD}_{2} \mathrm{Cl}_{2}$ at $193 \mathrm{~K}$, we detected simultaneously resonances from the starting copper(I) precursor and the $\left[\mathrm{Cu}_{2}{ }_{2}(\mu-\mathrm{O})_{2}(\mathrm{~L})_{2}\right]^{2+}$ species.

\section{Reaction of $\left[\mathrm{Cu}_{2}{ }_{2}(\mu-\mathrm{O})_{2}(\mathrm{~L})_{2}\right]^{2+}$ with $\mathrm{PPh}_{3}$}

The reactivity of $\mathbf{1}$ toward $\mathrm{PPh}_{3}$ was examined under both limiting dioxygen (anaerobic) and excess dioxygen (aerobic) conditions at different temperatures. When the reaction was studied under aerobic conditions, excess dioxygen was simply added to the precursor $\mathrm{Cu}(\mathrm{I})$ complex during the formation of the bis( $\mu$-oxo)dicopper(III) complex. For anaerobic conditions any excess $\mathrm{O}_{2}$ remaining after the formation of the bis $(\mu-$ oxo)dicopper(III) complex was removed by bubbling Ar gas through the solution for $20 \mathrm{~min}$ at $193 \mathrm{~K}$. The reaction with $\mathrm{PPh}_{3}$ was followed for different reaction times as the experimental mixture was warmed in steps.

To a solution of complex 1 prepared as mentioned above, 2 equiv. of a precooled solution of $\mathrm{PPh}_{3}$ in $\mathrm{CH}_{2} \mathrm{Cl}_{2}$ was introduced and aliquots of the experimental mixture were analyzed with time. This amount of $\mathrm{PPh}_{3}$ was chosen so that only $50 \%$ would be converted to $\mathrm{O}=\mathrm{PPh}_{3}$ if only one of the bridging oxos in the $\mathrm{Cu}_{2} \mathrm{O}_{2}$ core of complex 1 was transferred to the $\mathrm{PPh}_{3}$ during the oxo-transfer reaction and the reaction proceeded to completion. When the reaction was performed in the absence of excess dioxygen, negligible substrate $\left(\mathrm{PPh}_{3}\right)$ oxidation was observed. However, when the reaction was carried out under aerobic conditions, as can be seen in Fig. 1, at reaction time $5 \mathrm{~min}, 11 \%$ of the $\mathrm{PPh}_{3}$ was already oxidized to $\mathrm{O}=\mathrm{PPh}_{3}$. The yield of $\mathrm{O}=\mathrm{PPh}_{3}$ increased slowly, reaching $\sim 16.5 \%$ in $5 \mathrm{~h}$ and $\sim 20 \%$ in $10 \mathrm{~h}$ at $193 \mathrm{~K}$. Since the $\mathrm{PPh}_{3}$ was in excess of the dicopper complex 1 in these experiments, these observations must clearly reflect the thermodynamics of the oxo-transfer reaction, namely

$$
1+\mathrm{PPh}_{3} \rightleftharpoons \mathrm{O}=\mathrm{PPh}_{3}+\mathbf{2}
$$

rather than the equilibrium between the bis( $\mu$-oxo) and side-on peroxo isomers of $\mathbf{1}$.

Both the extent of conversion of the $\mathrm{PPh}_{3}$ to $\mathrm{O}=\mathrm{PPh}_{3}$ and the kinetics increased with temperature. The $20 \%$ conversion of $\mathrm{PPh}_{3}$ to $\mathrm{O}=\mathrm{PPh}_{3}$ that took $10 \mathrm{~h}$ at $193 \mathrm{~K}$ could be attained within a reaction time of $15 \mathrm{~min}$ at $233 \mathrm{~K}$. Slow warming of

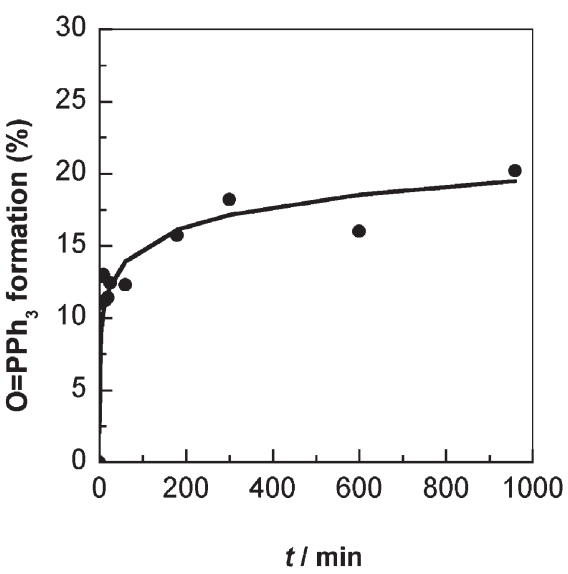

Fig. 1 Formation of $\mathrm{O}=\mathrm{PPh}_{3}$ calculated according to the stoichiometry of the reaction between 1 and $\mathrm{PPh}_{3}$ in dichloromethane at $193 \mathrm{~K}$ under dioxygen as described by Scheme 3. $[\mathbf{1}]_{0}=1.0 \mathrm{mM},\left[\mathrm{PPh}_{3}\right]_{0}=$ $2.0 \mathrm{mM},\left[\mathrm{O}_{2}\right]_{0}=6.58 \mathrm{mM}$.

the experimental solution and keeping the sample at room temperature for one day yielded $43 \%$ conversion of the $\mathrm{PPh}_{3}$ into $\mathrm{O}=\mathrm{PPh}_{3}$ (Table 1). The latter conversion was practically quantitative, if one took into consideration that there was a competing process of oxidative ligand $\mathrm{N}$-dealkylation (vide infra) at the higher temperatures $(\geq 233 \mathrm{~K})$. Thus 1 was competent toward effecting an oxo-transfer reaction converting $\mathrm{PPh}_{3}$ into $\mathrm{O}=\mathrm{PPh}_{3}$ under aerobic conditions. The process appeared to involve a stoichiometry of $1: 1$ with respect to 1 and $\mathrm{PPh}_{3}$, or only one of the two oxo-ligands in the bis $(\mu-$ oxo)dicopper(III) complex. The experimental data obtained are comparable to those previously reported, ${ }^{14}$ namely, the reactivity of 1 toward $\mathrm{PPh}_{3}$ at $193 \mathrm{~K}$ lies between two closely related bis( $\mu$-oxo)dicopper(III) complexes, one supported by $N, N^{\prime}$ di-tert-butyl- $N, N^{\prime}$-dimethyl-1,2-ethanediamine $(50 \%$ yield of $\mathrm{PPh}_{3} \mathrm{O}$ ) and the other by $N, N^{\prime}$-diisopropyl- $N, N^{\prime}$-dimethyl-1,2ethanediamine $\left(\sim 5 \%\right.$ yield of $\left.\mathrm{PPh}_{3} \mathrm{O}\right)$. However, the authors quenched the reaction by adding ammonia to aliquots of the experimental mixture at room temperature. In contrast, in the present study, we demonstrated that warming of the reaction mixture to room temperature led to substantial enhancement of the reaction rate and almost complete oxygen-atom transfer.

\section{Kinetic studies}

The reaction between bis( $\mu$-oxo)dicopper(III) complex 1 and triphenylphosphine was followed spectrophotometrically by the intensity decrease of the characteristic absorbance at $404 \mathrm{~nm}$ due to the complex 1 in $\mathrm{CH}_{2} \mathrm{Cl}_{2}$ at $193 \mathrm{~K}$. The reaction obeyed first-order kinetics in the presence of an excess amount of the $\mathrm{PPh}_{3}$ under dioxygen conditions over the first 160 min (Fig. 2), and the rate constant was well described by the initial rate over the first $300 \mathrm{~s}$ (Fig. 2, inset). A plot of the pseudo-firstorder rate constant $k_{\text {obs }}$ against the initial concentration of triphenylphosphine under aerobic conditions provided a straight line: $y=0.033 x+\left(1 \times 10^{-6}\right)\left(R^{2}=0.9865\right)$ with nearly zero intercept and a slope from which the pseudo-second-order rate constant $(3.3 \pm 0.3) \times 10^{-2} \mathrm{M}^{-1} \mathrm{~s}^{-1}$ was obtained at the dioxygen concentration of $6.58 \mathrm{mM}$ used (Fig. S1, ESI $\dagger$ ).

When the reaction was carried out under Ar conditions, practically no change in absorbance was observed. Thus, the rate of the reaction was unequivocably established to be dioxygen concentration dependent. A plot of the initial reaction rates measured at a fixed $\mathrm{PPh}_{3}$ concentration $v s$. the initial concentration of $\mathrm{O}_{2}$ could be fitted to a straight line: $y=0.013 x+\left(6 \times 10^{-6}\right)$ $\left(R^{2}=0.9856\right)$ with essentially zero intercept and the pseudosecond-order rate constant $(1.3 \pm 0.1) \times 10^{-2} \mathrm{M}^{-1} \mathrm{~s}^{-1}$ was obtained at the $\mathrm{PPh}_{3}$ concentration of $2.3 \mathrm{mM}$ used (Fig. S2, ESI $\dagger$ ). This result shows that the reaction is first order in dioxygen. In other words, dioxygen is serving as a catalyst in the oxo-transfer between complex 1 and $\mathrm{PPh}_{3}$. 


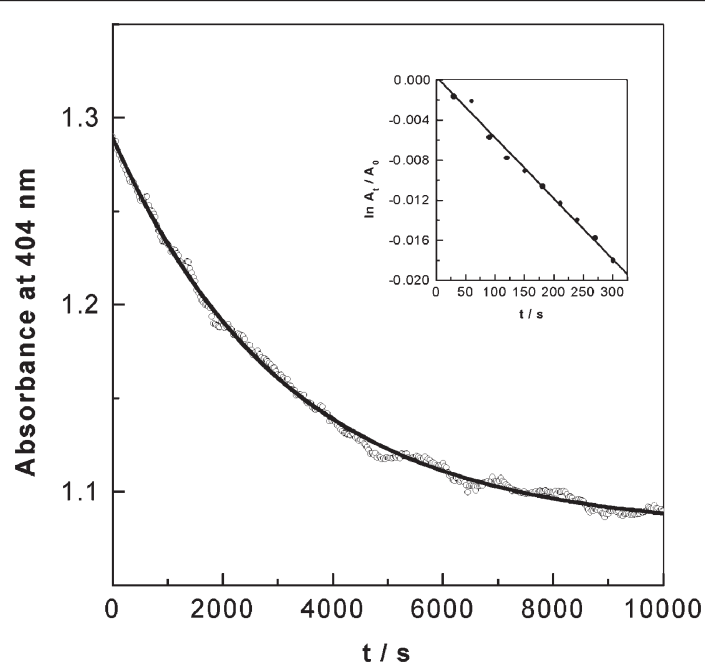

Fig. 2 A representative kinetic trace of the absorbance change at $404 \mathrm{~nm}$ during the reaction of 1 with excess $\mathrm{PPh}_{3}$ in dichloromethane at $193 \mathrm{~K}$ under dioxygen. Experimental points superimposed by singleexponential fit: $[\mathbf{1}]_{0}=0.053 \mathrm{mM},\left[\mathrm{PPh}_{3}\right]_{0}=1.7 \mathrm{mM},\left[\mathrm{O}_{2}\right]_{0}=6.58 \mathrm{mM}$. Inset: Plot of $\ln \left(A_{t} / A_{0}\right)$ vs. time based on the absorption change at $404 \mathrm{~nm}$ over the first $300 \mathrm{~s}$ and the corresponding linear fit.

To account for the experimental observations and to clarify the role of dioxygen, we have invoked the reaction mechanistic scheme shown in Scheme 2. We assume a rapid reaction between $\mathbf{1}$ and dioxygen to give an intermediate $\mathbf{1 a}$, followed by a slower oxo-transfer from 1a to $\mathrm{PPh}_{3}$ to give the product $\mathrm{O}=\mathrm{PPh}_{3}$ under the excess $\mathrm{PPh}_{3}$ and dioxygen concentrations used in these experiments. In other words, we assume that the oxo-transfer reaction is preceded by the formation of a dioxygen adduct of the bis( $\mu$-oxo)dicopper(III) complex 1. The dioxygen that is invoked as the catalyst in step (a) is regenerated in step (b). Finally, since we are recording the kinetics at early times (initial rates), the slow step is assumed to be irreversible.

$$
\begin{aligned}
& \text { (a) } 1+\mathrm{O}_{2} \frac{k_{1}-1 \mathrm{a}}{k_{-1}} \\
& \text { (b) } 1 \mathrm{a}+\mathrm{PPh}_{3} \frac{\mathrm{k}_{2} \longrightarrow \mathrm{O}=\mathrm{PPh}_{3}+\mathrm{O}_{2}+2}{\text { Scheme } 2}
\end{aligned}
$$

Although no detectable intermediate was observed during the course of the kinetic measurements, we assume that 1a was just present in the reaction mixture in miniscule amounts, and it was being consumed essentially as it is produced. Applying the steady-state assumption to the concentration of 1a yielded the following rate law for the overall reaction (eqn. (1)):

$$
\text { Rate }=-\mathrm{d}[1] / \mathrm{d} t=\frac{k_{1} k_{2}[1]\left[\mathrm{O}_{2}\right]\left[\mathrm{PPh}_{3}\right]}{k_{-1}+k_{2}\left[\mathrm{PPh}_{3}\right]}
$$

From this result, it is clear that pseudo-first-order conditions would be obtained with the dioxygen concentration fixed at $\left[\mathrm{O}_{2}\right]_{0}$, and when the kinetics was followed with the system flooded with respective to $\mathrm{PPh}_{3}$ and set at $\left[\mathrm{PPh}_{3}\right]_{0}$; that is,

$$
\text { Rate }=k_{\mathrm{obs}}[\mathbf{1}]
$$

where

$$
k_{\mathrm{obs}}=\frac{k_{1} k_{2}\left[\mathrm{PPh}_{3}\right]_{0}\left[\mathrm{O}_{2}\right]_{0}}{k_{-1}+k_{2}\left[\mathrm{PPh}_{3}\right]_{0}}
$$

Moreover, when step (b) is sufficiently slow compared with step (a) in the kinetic scheme to allow a pre-equilibrium to be established in step (a), $k_{2}\left[\mathrm{PPh}_{3}\right]_{0} \ll k_{-1}$, and

$$
k_{\mathrm{obs}}=\frac{k_{1} k_{2}\left[\mathrm{PPh}_{3}\right]_{0}\left[\mathrm{O}_{2}\right]_{0}}{k_{-1}}
$$

or

$$
k_{\mathrm{obs}}=K k_{2}\left[\mathrm{PPh}_{3}\right]_{0}\left[\mathrm{O}_{2}\right]_{0}=k_{2}{ }^{\prime}\left[\mathrm{PPh}_{3}\right]_{0}\left[\mathrm{O}_{2}\right]_{0}
$$

where $K=k_{1} / k_{-1}$ and $k_{2}{ }^{\prime}=k_{2} K$.

Thus, under pseudo-first order conditions, $k_{\text {obs }}$ should be a linear function of $\left[\mathrm{PPh}_{3}\right]_{0}$ under fixed aerobic conditions. Similarly, under fixed $\left[\mathrm{PPh}_{3}\right]_{0}, k_{\mathrm{obs}}$ should increase linearly with increasing $\left[\mathrm{O}_{2}\right]_{0}$. Since earlier we determined experimentally that $k_{2}{ }^{\prime}\left[\mathrm{O}_{2}\right]_{0}=(3.3 \pm 0.3) \times 10^{-2} \mathrm{M}^{-1} \mathrm{~s}^{-1}$ and $k_{2}{ }^{\prime}\left[\mathrm{PPh}_{3}\right]_{0}=(1.3 \pm$ $0.1) \times 10^{-2} \mathrm{M}^{-1} \mathrm{~s}^{-1}$, the two sets of experiments yielded $k_{2}{ }^{\prime}$ values that agreed within the experimental error of $\sim 10 \%$.

$$
\begin{aligned}
& k_{2}^{\prime}=\frac{k_{\mathrm{obs}}}{\left[\mathrm{O}_{2}\right]_{0}}=\frac{(3.3 \pm 0.3) \times 10^{-2} \mathrm{M}^{-1} \mathrm{~s}^{-1}}{6.58 \times 10^{-3} \mathrm{M}}=5.0 \pm 0.4 \mathrm{M}^{-2} \mathrm{~s}^{-1} \\
& k_{2}^{\prime}=\frac{k_{\mathrm{obs}}}{\left[\mathrm{PPh}_{3}\right]_{0}}=\frac{(1.3 \pm 0.1) \times 10^{-2} \mathrm{M}^{-1} \mathrm{~s}^{-1}}{2.3 \times 10^{-3} \mathrm{M}}=5.6 \pm 0.4 \mathrm{M}^{-2} \mathrm{~s}^{-1}
\end{aligned}
$$

\section{EPR and Cu K-edge absorption spectroscopy}

In order to monitor any changes in the $\mathrm{Cu}$ oxidation state during the reaction with $\mathrm{PPh}_{3}$, aliquots of the experimental mixtures were taken at $193 \mathrm{~K}$ at different reaction times and subjected to EPR and $\mathrm{Cu} \mathrm{K}$-edge $\mathrm{X}$-ray absorption spectroscopy. The experimental solutions examined at different reaction times were EPR silent, that is, no paramagnetic species were formed in significant quantities over the course of the reaction, or only diamagnetic species were involved.

The solutions, studied by EPR, were also examined by $\mathrm{Cu}$ K-edge X-ray absorption spectroscopy. Reaction of $\mathbf{1}$ with $\mathrm{PPh}_{3}$ under aerobic conditions resulted in the spectral changes shown in Fig. 3. Most significantly, the spectrum of $\mathbf{1}$ exhibited a pre-edge feature, centered at $8981.1 \mathrm{eV}$, corresponding to the $1 \mathrm{~s} \rightarrow 3 \mathrm{~d}$ transition of $\mathrm{Cu}(\mathrm{III}),{ }^{21}$ and also specific transitions at 8986.7 and $8993.2 \mathrm{eV}$, which could be assigned, respectively, as the $1 \mathrm{~s} \rightarrow 4 \mathrm{p}+\mathrm{LMCT}$ shakedown and $1 \mathrm{~s} \rightarrow 4 \mathrm{p}$ transitions. ${ }^{21,23}$ These features were more easily discerned in second derivative spectra (Fig. 4), where the positions of the peaks became more prominent against the background. As a result of the chemistry between 1 and $\mathrm{PPh}_{3}$ the intensity of the $1 \mathrm{~s} \rightarrow 3 \mathrm{~d}$ transition decreased, and a pre-edge feature at 8978.2, corresponding to $\mathrm{Cu}(\mathrm{II}),{ }^{23}$ appeared. In addition, a shift to lower energy $(\sim 0.4 \mathrm{eV})$ to $8986.3 \mathrm{eV}$ was also observed for the $1 \mathrm{~s} \rightarrow 4 \mathrm{p}+$ LMCT shakedown and $(\sim 0.6 \mathrm{eV})$ to $8992.6 \mathrm{eV}$ for the $1 \mathrm{~s} \rightarrow 4 \mathrm{p}$ transitions. When the reaction was carried out under excess of dioxygen

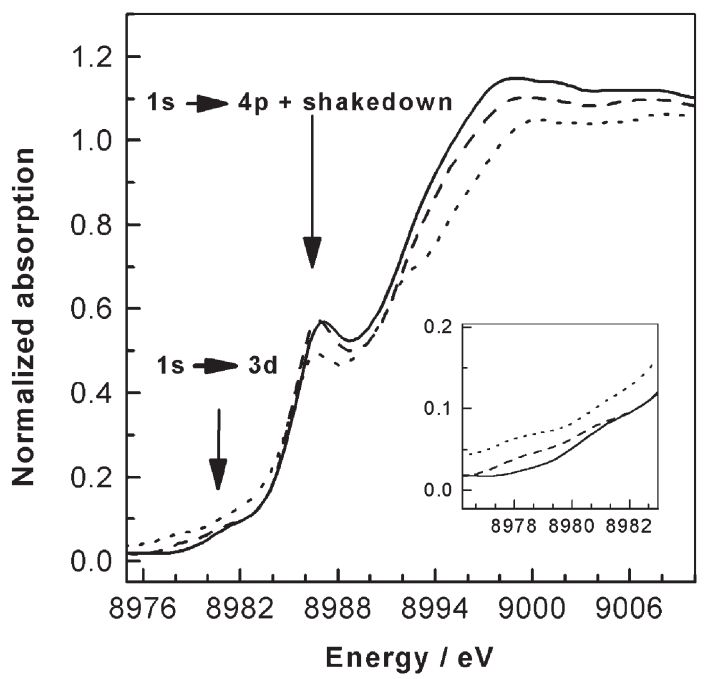

Fig. $3 \mathrm{Cu} \mathrm{K}$-edge $\mathrm{X}$-ray absorption recorded at $77 \mathrm{~K}$ for $\mathbf{1}$ (solid line), and after the reaction of 1 with $\mathrm{PPh}_{3}$ under excess dioxygen for $30 \mathrm{~min}$ (dashed line) and $4 \mathrm{~h}$ (dotted line) in $\mathrm{CH}_{2} \mathrm{Cl}_{2}$ at $193 \mathrm{~K}$. Inset: Pre-edge region amplified. 


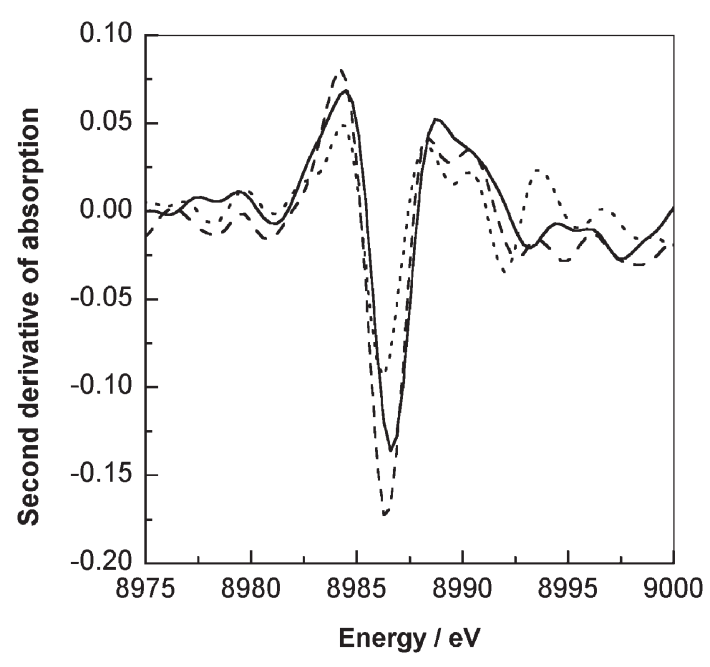

Fig. 4 Second-derivative of the $\mathrm{Cu}$ K-edge absorption recorded at $77 \mathrm{~K}$ for 1 (solid line); and after the reaction of 1 with $\mathrm{PPh}_{3}$ under excess dioxygen for $30 \mathrm{~min}$ (dashed line) and for $4 \mathrm{~h}$ (dotted line) in $\mathrm{CH}_{2} \mathrm{Cl}_{2}$ at $193 \mathrm{~K}$.

for more then $4 \mathrm{~h}$, there was further increase in the intensity of the features at $8978.2 \mathrm{eV}$ and at $8992.0 \mathrm{eV}$, which are typically observed for tetragonal $\mathrm{Cu}(\mathrm{II})$ complexes. $^{24}$

Taking into account that the reaction between complex 1 and $\mathrm{PPh}_{3}$ occurs principally in the presence of dioxygen and diamagnetic copper(II) species are formed, these observations are consistent with the reaction scheme highlighted in Scheme 2. First, the overall oxo-atom transfer from the bis( $\mu$-oxo)dicopper(III) core of 1 to $\mathrm{PPh}_{3}$ is $1: 1$. However, an essential feature of the oxo-atom transfer chemistry is that the reaction is catalyzed by dioxygen. The kinetics suggest that the dioxygen forms an adduct with complex $\mathbf{1}$, and it is this adduct that mediates the transfer of one of the bridging oxo atoms in the bis( $\mu$-oxo)dicopper(III) complex to $\mathrm{PPh}_{3}$ to form $\mathrm{O}=\mathrm{PPh}_{3}$. Had both oxo atoms of the bis( $\mu$-oxo)dicopper(III) core of 1 been transferred to $\mathrm{PPh}_{3}$ molecules, then the original $\mathrm{Cu}(\mathrm{I})$ precursor would be regenerated. In this scenario, the overall chemistry would then be described by the reaction $2 \mathrm{PPh}_{3}+\mathrm{O}_{2}$ $\rightarrow 2 \mathrm{O}=\mathrm{PPh}_{3}$, with the $\mathrm{Cu}(\mathrm{I})$ precursor serving as the catalyst. Finally, $\mathbf{1}$ is reduced to the diamagnetic complex $\mathbf{2}$, in accordance with Scheme 3.

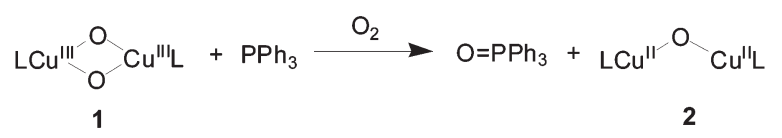

Scheme 3

However, contrary to expectation, the reaction does not proceed to completion at $193 \mathrm{~K}$, despite the strong acidity of the $\mathrm{PPh}_{3}$. Presumably, the $\mu$-oxo in the bis( $\mu$-oxo)dicopper(III) core is sufficiently stable that the overall equilibrium (Scheme 2) remains very much to the left at $193 \mathrm{~K}$. As the temperature is increased, the position of the equilibrium Scheme 2 is gradually shifted, until at room temperature the reaction is essentially complete (Table 1). We have established that such an equilibrium is indeed in effect by following the reaction to longer times (kinetics no longer fit exponential behavior after several hours) as well as observing the effects of exogenously added products on the overall kinetics. The addition of $\mathrm{O}=\mathrm{PPh}_{3}$ to our reaction mixtures has been found to accelerate the approach of the system toward chemical equilibrium (Fig. S3, ESI $\dagger$ ).

\section{The oxo-bridged dicopper(II) complex}

As a consequence of the chemistry highlighted in Schemes 2 and 3 , the oxidation state of the copper centers in the bis $(\mu-$ oxo)dicopper(III) complex would change from +3 to +2 , as confirmed by X-ray absorption edge results. Many examples of ( $\mu$-oxo)dicopper(II) complexes are known. ${ }^{25-31}$ Most of
Table 1 Conversion of $\mathrm{PPh}_{3}$ into $\mathrm{O}=\mathrm{PPh}_{3}(\%)$ for the reaction time 15 min in $\mathrm{CH}_{2} \mathrm{Cl}_{2}$

\begin{tabular}{lll}
\hline Temperature/K & Aerobic condition & Anaerobic condition \\
\hline 193 & 11.0 & 3 \\
203 & 14.2 & - \\
213 & 14.7 & - \\
223 & 16.5 & - \\
233 & 17.8 & - \\
Further, slow warming & 42.8 & \\
to room temperature. & & \\
& & \\
\hline
\end{tabular}

them demonstrate antiferromagnetic properties and their frozen solutions are EPR silent at $77 \mathrm{~K} .{ }^{27,29}$ But only a few of these ( $\mu$-oxo)dicopper(II) compounds have been isolated, ${ }^{25,27,29}$ because of their instability and strong nucleophilic properties. In polar solvents, like methanol, ( $\mu$-oxo)dicopper(II) species disproportionate to mononuclear $\mathrm{Cu}(\mathrm{II})$ complexes. ${ }^{28,29}$ In the presence of small amounts of water, these complexes are also known to transform into the bis( $\mu$-hydroxo)dicopper(II) species 3, ${ }^{28-31}$ (Scheme 4).

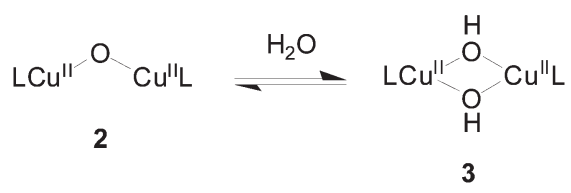

Scheme 4

Our attempts to isolate ( $\mu$-oxo)dicopper(II) complex 2 resulted in separation of the bis( $\mu$-hydroxo)dicopper(II) compound 3, which we have characterized by X-ray crystallography. The structural characteristics of the obtained complex were analogous to those previously reported. ${ }^{32}$ Complex 3 crystallized in the $P 2_{1} / c$ monoclinic system. The coordination geometry around copper atom is slightly distorted from planarity, consisting of the $\mathrm{N}_{2} \mathrm{O}_{2}$ donor set defined by the two bridging $\mathrm{OH}$ groups and the two nitrogens from the bidentate ligands. The IR spectrum of this compound included sharp bands at 3518 and $3423 \mathrm{~cm}^{-1}$, which corresponded to the $\mathrm{O}-\mathrm{H}$ stretching vibrations from the bridging hydroxo groups and from lattice water, respectively. Complex 3 is EPR silent ( $77 \mathrm{~K}$ ), and exhibited a broad d-d absorption at $\lambda=560 \mathrm{~nm}\left(\varepsilon 260 \mathrm{M}^{-1} \mathrm{~cm}^{-1}\right)$ and an intense feature at $\lambda=361 \mathrm{~nm}\left(\varepsilon 1500 \mathrm{M}^{-1} \mathrm{~cm}^{-1}\right)$. The latter could be ascribed to a $\mathrm{OH}^{-} \rightarrow \mathrm{Cu}(\mathrm{II}) \mathrm{LMCT}$ transition, as found for other bis $(\mu-$ hydroxo)dicopper(II) complexes. ${ }^{30,31,33}$ The perchlorate anion was not coordinated to the metal, but there are hydrogen bond interactions between one of the oxygens of the perchlorate group and the bridging hydroxide group.

Finally, Kitajima et al. ${ }^{27,29}$ and Karlin et al. ${ }^{28}$ reported the facile oxidation of $\mathrm{PPh}_{3}$ by the related ( $\mu$-oxo)dicopper(II) species under ambient temperature with replacement of the oxygen atom in the ( $\mu$-oxo)dicopper(II) species by $\mathrm{PPh}_{3}$ molecule and the generation of $\mathrm{Cu}(\mathrm{I})-\mathrm{PPh}_{3}$ complexes. However, no $\mathrm{Cu}(\mathrm{I})$ complexes were observed in the reaction of 1 with $\mathrm{PPh}_{3}$ in the present study. Thus, we have obtained no evidence for the reaction $1+4 \mathrm{PPh}_{3} \rightarrow 2 \mathrm{O}=\mathrm{PPh}_{3}+2 \mathrm{LCu}(\mathrm{I})-\mathrm{PPh}_{3}$.

\section{Isotope-labeling experiments}

In order to verify the role of the exogenous dioxygen in the reaction of 1 with $\mathrm{PPh}_{3}$ and in an attempt to probe the nature of the dioxygen adduct formed with the bis( $\mu$-oxo)dicopper(III), namely 1a, we have performed a series of isotope-labeling experiments, where either ${ }^{16} \mathrm{O}_{2}$ and/or ${ }^{18} \mathrm{O}_{2}$ was used in the preparation of $\mathbf{1}$, and the final outcome of the bridging oxo in $\mathbf{1}$ was queried in the product $\mathrm{O}=\mathrm{PPh}_{3}$ in the presence of the dioxygen bearing the other isotopomer. The results of these experiments are schematically presented in Scheme 5(a, b, c). 
(a)

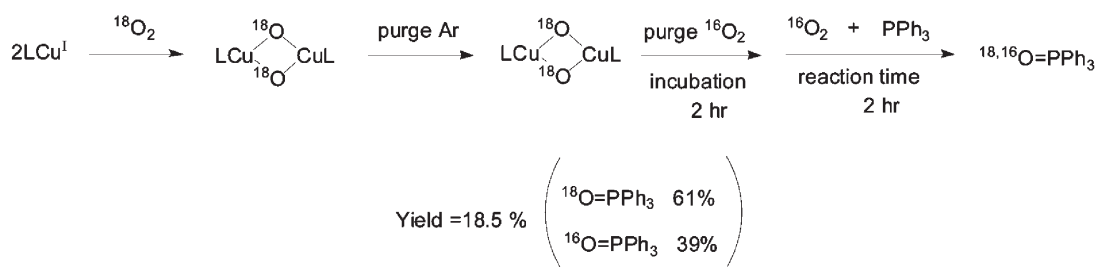

(b)

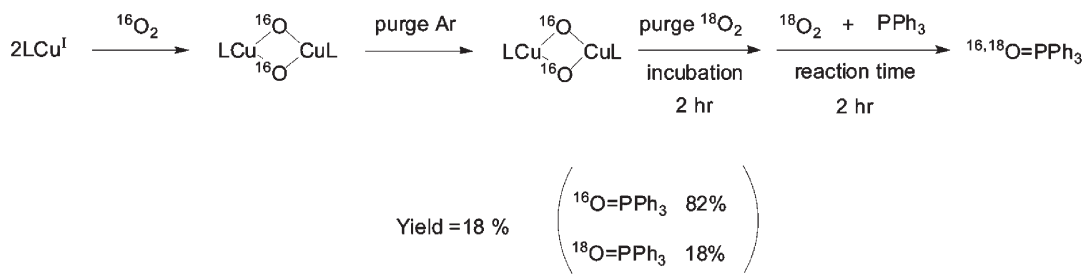

(c)

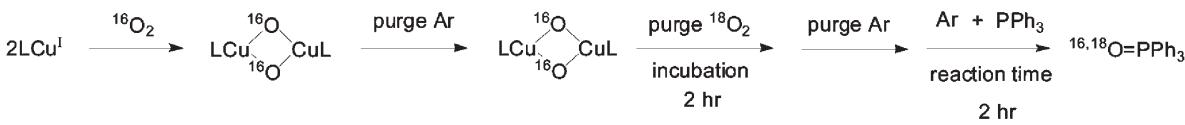

$$
\begin{aligned}
& \text { Yield }=4 \%\left(\begin{array}{cc}
{ }^{16} \mathrm{O}=\mathrm{PPh}_{3} & 98 \% \\
{ }^{18} \mathrm{O}=\mathrm{PPh}_{3} & 2 \%
\end{array}\right)
\end{aligned}
$$

Scheme 5

These isotope-labeling experiments clearly demonstrated that the oxygen atom transferred to the $\mathrm{PPh}_{3}$ came both from the bis( $\mu$-oxo)dicopper(III) complex and the exogenous dioxygen, as expected for a process that was catalyzed by the dioxygen via the formation of an "active species". In other words, there was scrambling of the oxygen isotopes from $\mathbf{1}$ and the dioxygen either during the formation of $\mathbf{1 a}$ or during the oxo-transfer reaction from 1a to $\mathrm{PPh}_{3}$. However, the data did suggest that the oxo atom transferred to the $\mathrm{PPh}_{3}$ came primarily from the bis( $\mu$-oxo)dicopper(III) complex, and there was only partial scrambling of the oxygen atoms between the $\mu$-oxos in the bis( $\mu$-oxo)dicopper(III) complex and the dioxygen in the adduct. Moreover, it was clear from the results obtained for (c) in Scheme 5 that the direct exchange between the oxygen pools between the bis( $\mu$-oxo)dicopper(III) complex and the exogenous dioxygen was too slow to affect the outcome of the isotope labeling experiments. In this control experiment, we observed only $2 \%$ of the exogenous dioxygen $\left({ }^{18} \mathrm{O}_{2}\right)$ in the product $\left(\mathrm{O}=\mathrm{PPh}_{3}\right)$ after a prolonged equilibration between complex $\mathbf{1}$, that had previously been labeled with ${ }^{16} \mathrm{O}_{2}$, with the exogenous dioxygen ${ }^{18} \mathrm{O}_{2}$, followed by purging with $\mathrm{Ar}$ and re-equilibration with fresh $\mathrm{Ar}$ and $\mathrm{PPh}_{3}$. Under these conditions, the oxo-transfer was presumably non-catalytic, so that the rate was very slow and only a small quantity of $\mathrm{O}=\mathrm{PPh}_{3}$ was produced by direct reaction of the $\mathrm{PPh}_{3}$ with the bridging oxos in the bis( $\mu$-oxo)dicopper(III) complex. Thus, the scrambling of the oxygen isotopes in these experiments did not occur during the formation of 1a, but rather during the oxo-transfer reaction from 1 a to $\mathrm{PPh}_{3}$.

\section{Mechanistic considerations}

The results of the ${ }^{16} \mathrm{O}_{2} /{ }^{18} \mathrm{O}_{2}$ isotope labeling experiments are consistent with the reaction scheme proposed in Scheme 2. But at this stage we can only speculate upon the nature of the "reactive species" 1a, which are undetectable under experimental conditions. One possibility is that $\mathbf{1 a}$ is a $(\mu$-oxo $)(\mu(1,1)$ ozonide)dicopper(III) complex, namely, dioxygen has merely added to one of the bridging $\mu$-oxos in $\mathbf{1}$ to form an "oxonide" adduct (structure $\mathbf{A}$ in Scheme 6). Such an adduct should be relatively labile, which would account for the rapid preequilibrium given by step (a) in Scheme 2. More importantly, the ozonide formation is expected to activate the remaining

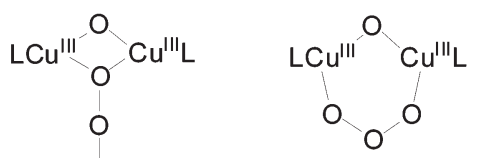

$$
\begin{aligned}
& \text { A B }
\end{aligned}
$$

$\mu$-oxo in the adduct, rendering it more facile for oxo-atom transfer to $\mathrm{PPh}_{3}$ to form $\mathrm{O}=\mathrm{PPh}_{3}$. This scenario would fit well with the limiting ${ }^{16} \mathrm{O}_{2} /{ }^{18} \mathrm{O}_{2}$ isotope scrambling results. At this juncture, we could not rule out other structures for the adduct 1a, for example, structures $\mathbf{B}$ and $\mathbf{C}$ in Scheme 6, although structure $\mathbf{B}$ is expected to lead to greater ${ }^{16} \mathrm{O}_{2} /{ }^{18} \mathrm{O}_{2}$ isotope scrambling than observed experimentally.

It is conceivable that the exogenous dioxygen somehow promotes the formation of the side-on peroxo isomer by shifting the equilibrium between the bis( $\mu$-oxo) and side-on peroxo forms. It has been shown ${ }^{14,15,20}$ that the peroxo-isomer is a better oxygen-atom transfer reagent, so that under rapid interconversion between the two isomers, ${ }^{14,33}$ the oxo-transfer from complex 1 to $\mathrm{PPh}_{3}$ could be facilitated. Although this hypothesis is quite attractive, under our experimental conditions, we have observed in the UV-vis spectra solely the absorbance from the bis( $\mu$-oxo)dicopper(III) isomer and a small shoulder at $360 \mathrm{~nm}$ (corresponding to the bis( $\mu$-hydroxo)dicopper(II) species), which appeared after the reaction of 1 with $\mathrm{PPh}_{3}$.

\section{Stoichiometric formation of copper(II) clusters of higher nuclearity}

As noted earlier, when the formation of the bis $(\mu-$ oxo)dicopper(III) complex and the reaction between 1 and $\mathrm{PPh}_{3}$ was carried out in dry $\mathrm{CH}_{2} \mathrm{Cl}_{2}$ under large excess of dioxygen, the diamagnetic species 2 was produced (Scheme 3). No EPR signal was observed for these reaction mixtures. However, when the formation of the bis( $\mu$-oxo)dicopper(III) complex was carried out under limiting dioxygen (less than stoichiometric to form the $2: 1 \mathrm{Cu}: \mathrm{O}_{2}$ complex totally), a strong isotropic signal with $g$ value centered at 2.11 was observed in the EPR spectrum (Fig. 5). Under these conditions, the excess $\mathrm{Cu}(\mathrm{I})$ starting precursor in the solution could provide a source of 

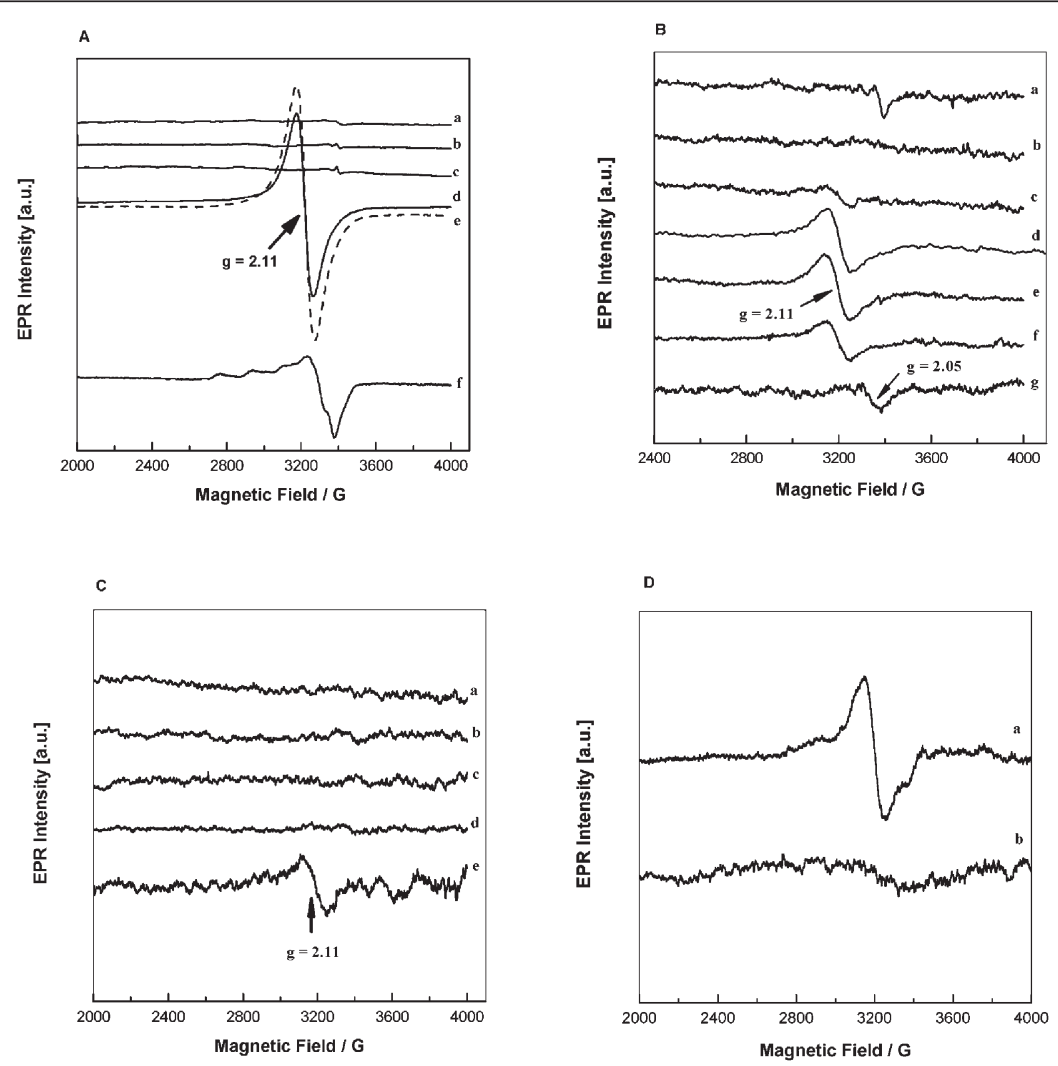

Fig. 5 EPR spectra (77 K) recorded during the reaction of 1 with $\mathrm{PPh}_{3}$ in $\mathrm{CH}_{2} \mathrm{Cl}_{2}$ at $193 \mathrm{~K}$ (A) Reaction followed under Ar (anaerobic conditions): (a) Spectrum of an initial solution of $1\left(4.3 \mathrm{mM}\right.$ ) without $\mathrm{PPh}_{3}$; (b)-(e) spectra recorded after reaction with $\mathrm{PPh}_{3}$ for 10 min (b), $1 \mathrm{~h} 30 \mathrm{~min}$ (c), $4 \mathrm{~h}$ (d), $\sim 12 \mathrm{~h}$ (e), and further warming to room temperature and work up with methanol (f). (B) Reaction followed under Ar (anaerobic conditions) using a sample of partially reduced 1 prepared by incomplete oxidation of the starting $\mathrm{Cu}(\mathrm{I})$ complex. (a) Spectrum of an initial solution of $\mathbf{1}(0.65 \mathrm{mM})$ without $\mathrm{PPh}_{3}$; (b)-(g) spectra recorded after reaction with $\mathrm{PPh}_{3}$ for $10 \mathrm{~min}(\mathrm{~b}), 20 \mathrm{~min}(\mathrm{c}), 1 \mathrm{~h}(\mathrm{~d}), 2 \mathrm{~h}(\mathrm{e}), 9 \mathrm{~h}$ (f) and further warming solution to room temperature with exposure to air (g). (C) Reaction followed under Ar (anaerobic conditions) using a sample of partially reduced $\mathbf{1}$ in the presence of $1 / 2$ equiv. of the $\mathrm{Cu}(\mathrm{I})$ precursor. (a) Spectrum of an initial solution of complex $1(0.65 \mathrm{mM})$; (b) spectrum obtained after introduction of $1 / 2$ equiv. of $\mathrm{Cu}(\mathrm{I})$ complex into the solution of $\mathbf{1}$; and (c)-(e) spectra obtained after reaction with $\mathrm{PPh}_{3}$ for $15 \mathrm{~min}$ (c), $1 \mathrm{~h}$ (d), and $\sim 12 \mathrm{~h}$ (e). (D) Reaction of $\mathbf{1}$ with $\mathrm{PPh}_{3}$ followed under $\mathrm{Ar}$ (anaerobic condition) for reaction time $\sim 12 \mathrm{~h}$ (a); and further warming to room temperature (b).

reducing equivalents to partially reduce some of the bis $(\mu-$ oxo)dicopper(III) complex already formed to give the mixed valence $\left[\mathrm{Cu}^{\mathrm{II}} \mathrm{Cu}^{\mathrm{III}}(\mu-\mathrm{O})_{2}\right]^{+}$core.

The experimental conditions that led to the formation of this new copper species are as follows: After incomplete oxygenation of a sufficiently concentrated solution $(8.7 \mathrm{mM})$ of the $\mathrm{Cu}(\mathrm{I})$ starting material, and the addition of 2 equivalents of $\mathrm{PPh}_{3}$, the experimental mixture was left stirring at $193 \mathrm{~K}$ under anaerobic conditions (1 atmosphere of argon). Initially, we detected practically no EPR spectra (Fig. 5(A)(a)-(c)). Then, at a reaction time of $\sim 3-4 \mathrm{~h}$, an isotropic signal was detected (Fig. 5(A)(d),(e)). The latter EPR signal is typical of $\mathrm{Cu}$ (II) complexes with octahedral symmetry, ${ }^{34}$ but is also found for symmetrical triangular copper(II) cluster complexes with equivalent $g_{x}, g_{y}, g_{z}$ values. ${ }^{35-37}$

The new copper species with the isotropic EPR signal was formed only when there was insufficient dioxygen in the sample to oxidize all the starting $\mathrm{Cu}(\mathrm{I})$ complex to the bis( $\mu$ oxo)dicopper(III) complex, and when the subsequent oxotransfer reaction to $\mathrm{PPh}_{3}$ was performed under Ar conditions. Despite the fact that the $\mathrm{PPh}_{3}$ was incubated with incompletely oxidized 1 under anaerobic conditions, relative facile oxidation of $\mathrm{PPh}_{3}$ to $\mathrm{O}=\mathrm{PPh}_{3}$ was observed in these experiments (vide infra). Typically, under anaerobic conditions, practically no oxo-atom transfer from 1 to $\mathrm{PPh}_{3}$ was observed.

In order to highlight these features, we summarize the results of several independent experiments in Fig. 5 and Table 2:

(1) As can be seen from Fig. 5(B)(a), under conditions of incomplete oxidation of the starting $\mathrm{Cu}(\mathrm{I})$ complex at $193 \mathrm{~K}$, we could register a weak EPR signal. This weak EPR spectrum most likely originated from the $\mathrm{Cu}(\mathrm{II})$ in the reoxidized starting material. It is possible that there was also a contribution from the mixed-valence $\left[\mathrm{Cu}^{\mathrm{II}} \mathrm{Cu}^{\mathrm{III}}(\mu-\mathrm{O})_{2}\right]^{+}$species that was expected to be formed after reduction of the bis( $\mu$-oxo)dicopper(III) complex by the excess starting $\mathrm{Cu}(\mathrm{I})$ precursor. Upon purging the sample with $\mathrm{Ar}$ and the introduction of $\mathrm{PPh}_{3}$, the EPR spectrum of the sample became silent. However, with time, a broadened isotropic signal with the characteristic $g=2.11$ grew in gradually (Fig. 5(B)(c)-(f)), as was observed before (Fig. 5(A)(d),(e)). Further warming of this sample to room temperature and exposure to dioxygen, resulted in a blue solution with a weak type $2 \mathrm{Cu}$ (II) EPR at $g \sim 2.05$ (Fig. 5(B)(g)). This experiment highlighted the requirement for excess reducing equivalents in the solution to give the copper species with the isotropic EPR signal as well as the relatively facile oxygen atom transfer from the mixed-valence $\left[\mathrm{Cu}^{\mathrm{II}} \mathrm{Cu}^{\mathrm{III}}(\mu-\mathrm{O})_{2}\right]^{+}$species to $\mathrm{PPh}_{3}$ at $193 \mathrm{~K}$ in $\mathrm{Ar}$ in this experiment.

(2) In a second set of experiments, we added $1 / 2$ equivalent of the $\mathrm{Cu}(\mathrm{I})$ starting material to a solution containing $0.65 \mathrm{mM}$ of the preformed bis( $\mu$-oxo)dicopper(III) species (total copper $1.95 \mathrm{mM}$ ) at $193 \mathrm{~K}$. No EPR signal was observed initially upon the introduction of $\mathrm{PPh}_{3}$ (under Ar). The broadened isotropic signal was detected after a reaction time of $\sim 12 \mathrm{~h}$. These spectral changes in the EPR pointed unequivocally to the generation of a new $\mathrm{Cu}$ (II) cluster species, whose concentration depended on the concentration of bis( $\mu$-oxo)dicopper(III) species as well as on the concentration of reducing equivalents available to partially reduce the preformed bis( $\mu$-oxo)dicopper(III) complex. When the concentration of the mixed valence $\left[\mathrm{Cu}^{\mathrm{II}} \mathrm{Cu}^{\mathrm{II}}(\mu-\mathrm{O})_{2}\right]^{+}$ species was higher as in the first set of experiments (Fig. 5(A)), the isotropic EPR signal was much more intense than in the present experiment (Fig. 5B, C(e), D(a)).

Although the structural details remained unclear, on the basis of the experimental observations summarized above, it is possible to propose the following scenario for the formation of the putative trinuclear copper cluster species. When there 
Table 2 Summary of experiments on $\left[\mathrm{Cu}_{2}{ }^{\mathrm{III}}(\mu-\mathrm{O})_{2}(\mathrm{~L})_{2}\right]^{2+}$ samples containing residual (due to incomplete oxidation) or added $[\mathrm{LCu}(\mathrm{PhCN})]^{+}$ precursor: Evidence for enhanced reactivity of $\left[\mathrm{Cu}^{\mathrm{II}} \mathrm{Cu}^{\mathrm{III}}(\mu-\mathrm{O})_{2}\right]^{+}$species towards oxo-transfer to $\mathrm{PPh}_{3}$

\begin{tabular}{|c|c|c|c|}
\hline Details on the preparation of the sample & Reaction time at $193 \mathrm{~K} / \mathrm{min}$ & EPR signal ( $g$-value) & Conditions \\
\hline $\begin{array}{l}\text { Experiment } 1 \\
\text { Initial concentration of }[\mathrm{LCu}(\mathrm{PhCN})]^{+}=8.7 \mathrm{mM} \text {; } \\
\text { complete formation of } 1(4.3 \mathrm{mM})\end{array}$ & $10-720$ & Silent & Aerobic \\
\hline $\begin{array}{l}\text { Experiment } 2 \\
\text { Initial concentration of }[\mathrm{LCu}(\mathrm{PhCN})]^{+}=8.7 \mathrm{mM} \text {; } \\
\text { incomplete formation of } \mathbf{1}(<4.3 \mathrm{mM})\end{array}$ & $\begin{array}{l}10-120 \\
240 \\
720\end{array}$ & $\begin{array}{l}\text { Silent } \\
\text { Isotropic }(2.1) \\
\text { Isotropic }(2.1)\end{array}$ & Anaerobic \\
\hline $\begin{array}{l}\text { Experiment } 3 \\
\text { Initial concentration of }[\mathrm{LCu}(\mathrm{PhCN})]^{+}=4.0 \mathrm{mM} \text {; } \\
\text { incomplete formation of } 1(<2.0 \mathrm{mM})\end{array}$ & 720 & Weak isotropic (2.1) & Anaerobic \\
\hline $\begin{array}{l}\text { Experiment } 4 \\
\text { Initial concentration of }[\mathrm{LCu}(\mathrm{PhCN})]^{+}=1.3 \mathrm{mM} \text {; } \\
\text { complete formation of } 1(0.65 \mathrm{mM}) \\
\text { Initial concentration of }[\mathrm{LCu}(\mathrm{PhCN})]^{+}=1.3 \mathrm{mM} \text {; } \\
\text { complete formation of } 1(0.65 \mathrm{mM}) \text {; } \\
\text { additional } \mathrm{Cu}(\mathrm{I}) \text { precursor }(0.35 \mathrm{mM}) \text { subsequently added }\end{array}$ & $\begin{array}{l}- \\
15-60 \\
720\end{array}$ & $\begin{array}{l}\text { Silent } \\
\text { Silent } \\
\text { Isotropic (2.1) }\end{array}$ & Anaerobic \\
\hline $\begin{array}{l}\text { Experiment } 5 \\
\text { Initial concentration of }[\mathrm{LCu}(\mathrm{PhCN})]^{+}=1.3 \mathrm{mM} \text {; } \\
\text { incomplete formation of } \mathbf{1}(<0.65 \mathrm{mM}) \\
\text { no additional } \mathrm{Cu}(\mathrm{I}) \text { precursor added }\end{array}$ & $\begin{array}{l}- \\
10 \\
20-540\end{array}$ & $\begin{array}{l}\text { Weak } \\
\text { Silent } \\
\text { Isotropic (2.1) }\end{array}$ & Anaerobic \\
\hline
\end{tabular}

was excess of reduced $\mathrm{Cu}(\mathrm{I})$ starting material in the sample during the preparation of the bis( $\mu$-oxo)dicopper(III) complex, or when there was insufficient dioxygen to transform all the starting material to the bis( $\mu$-oxo)dicopper(III) species, a mixedvalence copper(II,III)-dioxygen active species could be formed (Scheme 7). When this mixed-valence species further reacted with $\mathrm{PPh}_{3}$ under anaerobic conditions (under Ar), and there was a second mixed-valence complex to receive the extra electron from the product copper species remaining after the oxo-transfer reaction to $\mathrm{PPh}_{3}$, two trinuclear copper(II) clusters 4 would result (Scheme 7). Presumably it is this trinuclear copper(II) species that is the origin of the broad isotropic EPR signal at $g \sim 2.11$.

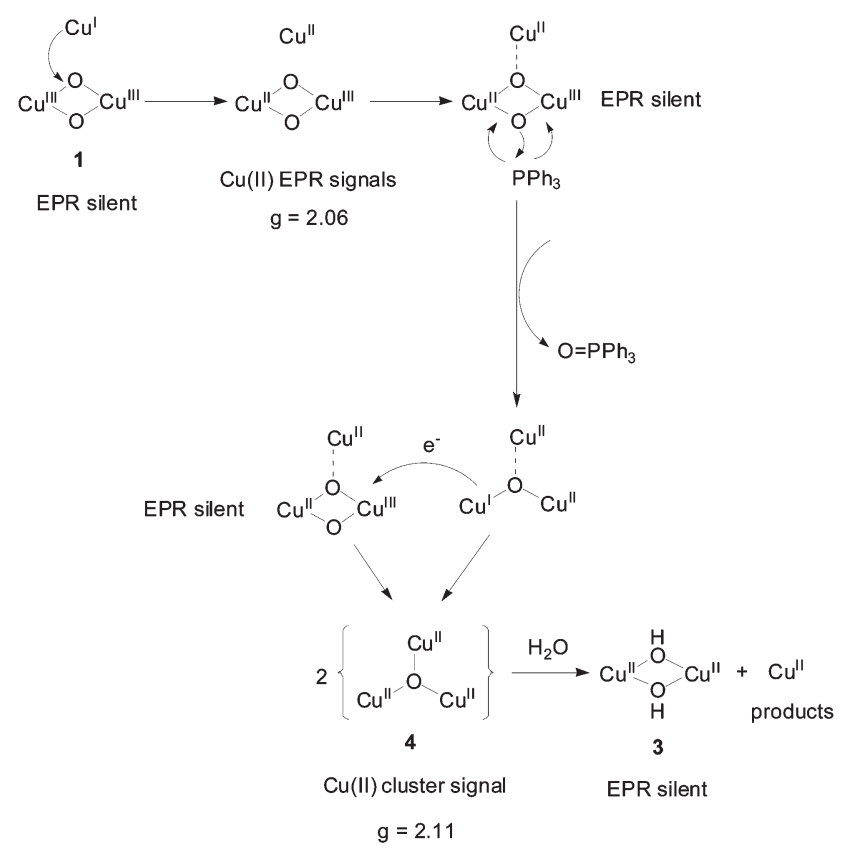

Scheme 7 Proposed scheme for the oxo-transfer reaction from partially reduced 1 to $\mathrm{PPh}_{3}$ and the formation of trinuclear copper(II) clusters under dioxygen limiting conditions.

Analysis of aliquots of the experimental mixture, examined at low temperatures, as well as integration of EPR spectra, showed that the percent of conversion of $\mathrm{PPh}_{3}$ into $\mathrm{O}=\mathrm{PPh}_{3}$ correlated well with the amount of trinuclear $\mathrm{Cu}(\mathrm{II})$ clusters formed, consistent with the chemistry proposed in Scheme 7. For example, in the first set of experiments (Fig. 5(A)), where we started with a $\mathrm{Cu}(\mathrm{I})$ concentration of $8.7 \mathrm{mM}, \sim 1.98 \mathrm{mM}$ was converted to $\mathrm{Cu}(\mathrm{II})$, according to the intensity of the EPR signal at $g=2.11$, after a $4 \mathrm{~h}$ incubation at $193 \mathrm{~K}$, corresponding to $\sim 22 \%$ conversion to $\mathrm{Cu}(\mathrm{II})$ based on the initial $\mathrm{Cu}(\mathrm{I})$ concentration. The observed conversion of $\mathrm{PPh}_{3}$ into $\mathrm{O}=\mathrm{PPh}_{3}$, based on quantitation of GC data, was consistent, with $\sim 15.4 \%$ conversion of the starting $\mathrm{Cu}(\mathrm{I})$ to $\mathrm{Cu}(\mathrm{II})$. After a reaction time of $16 \mathrm{~h}, 44 \%$ of the $\mathrm{Cu}(\mathrm{I})$ was converted to $\mathrm{Cu}(\mathrm{II})$ based on the formation of $\mathrm{O}=\mathrm{PPh}_{3}$ as detected by $\mathrm{GC}$; and the $\mathrm{Cu}$ (II) concentration was $\sim 3.4 \mathrm{mM}$, which corresponded to the oxidation of $39 \%$ of the starting $\mathrm{Cu}$ (I) to $\mathrm{Cu}$ (II). For comparison, when the oxo-atom transfer reaction was performed under excess dioxygen at $193 \mathrm{~K}$, the conversion of $\mathrm{PPh}_{3}$ into $\mathrm{O}=\mathrm{PPh}_{3}$ was about $16 \%$, after a reaction time of $5 \mathrm{~h}$. However, the solution was EPR silent indicating that only diamagnetic copper species were involved in the chemistry.

The oxo-transfer chemistry from the mixed-valence

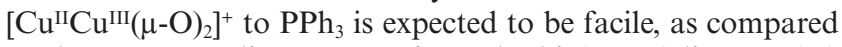
to the corresponding process from the bis( $\mu$-oxo)dicopper(III) complex, which has proven to be relatively inert. Earlier, we had already commented on the stability of the $\mu$-oxo in the bis( $\mu$-oxo)dicopper(III) core at $193 \mathrm{~K}$ in consideration of the thermodynamics of the oxo-atom transfer from the bis( $\mu$-oxo)dicopper(III) complex to $\mathrm{PPh}_{3}$. The corresponding oxo-atom transfer from the mixed-valence $\left[\mathrm{Cu}^{\mathrm{II}} \mathrm{Cu}^{\mathrm{III}}(\mu-\mathrm{O})_{2}\right]^{+}$ complex should be more favorable thermodynamically, as we have just demonstrated here. In other words, one electron titration of the bis( $\mu$-oxo)dicopper(III) core promotes oxo transfer from the cluster to $\mathrm{PPh}_{3}$ at $193 \mathrm{~K}$. Chan et al. ${ }^{38}$ has hypothesized such a mixed-valence $\left[\mathrm{Cu}^{\mathrm{II}} \mathrm{Cu}^{\mathrm{III}}(\mu-\mathrm{O})_{2}\right]^{+}$unit as an actual active oxygen intermediate in the alkane hydroxylation chemistry mediated by pMMO. More recently, it has also been demonstrated that the disproportionation of bis( $\mu$-oxo)dicopper(III) complex may afford a reactive intermediate such as $(\mu$-oxo) $(\mu-$ oxyl radical)dicopper(III) species, which may participate in the $\mathrm{C}-\mathrm{H}$ bond activation of external substrates. ${ }^{39}$

Unfortunately, our attempts to isolate the $\mathrm{Cu}(\mathrm{II})$ cluster complex was unsuccessful. Warming the resulting experimental mixture afforded a blue-green solution with a green precipitate. After separation and re-dissolving of the green precipitate in methanol, we obtained an EPR spectrum that is typical of $\mathrm{Cu}$ (II) ions in a quasi-square planar coordination environment ${ }^{34,40}$ (Fig. 5A(f)).

\section{NMR spectroscopy studies}

${ }^{1} \mathrm{H}$ NMR was also used to monitor the reaction between $\mathbf{1}$ and $\mathrm{PPh}_{3}$ under both aerobic and anaerobic conditions. Addition of 
$\mathrm{PPh}_{3}$ to a dichloromethane- $\mathrm{d}_{2}$ solution of $\mathbf{1}$ under excess oxygen at $193 \mathrm{~K}$ resulted in a decrease in the intensity of the resonances assigned to the bis( $\mu$-oxo)dicopper(III) complex (Fig. 6(A)) without any noticeable changes in the chemical shifts and linewidths of these signals.

An apparent equilibrium was reached after several hours, without further decrease in the intensity of the signals. Upon slow warming of the experimental mixture to ambient temperatures, however, the resonances of $\mathbf{1}$ completely disappeared, in part
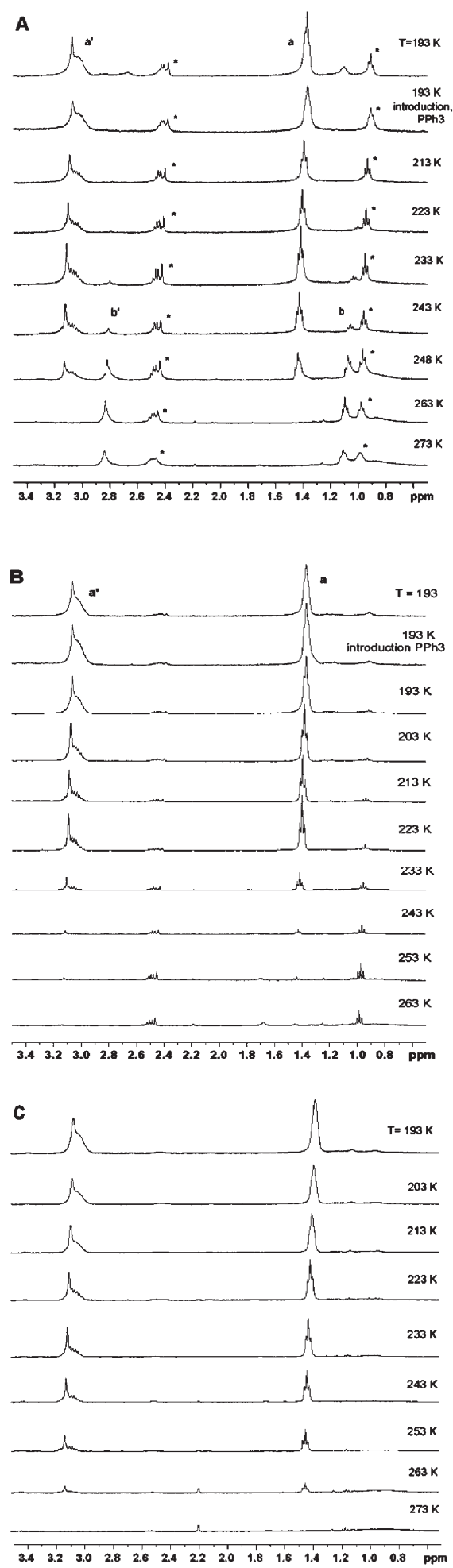

Fig. 6 Changes in the ${ }^{1} \mathrm{H}$ NMR spectra $\left(\mathrm{CD}_{2} \mathrm{Cl}_{2}\right)$ observed upon introduction of $\mathrm{PPh}_{3}$ into the solution of $\mathbf{1}$ under dioxygen conditions (A) and under anaerobic conditions (Ar) (B) followed by warming the reaction mixture to ambient temperature. $\left(\mathrm{a}, \mathrm{a}^{\prime}\right)$ denote the resonances from the $-\mathrm{CH}_{3}$ and $-\mathrm{CH}_{2}$ protons, respectively, of complex 1; resonances $\left(\mathrm{b}, \mathrm{b}^{\prime}\right)$ are assigned to the $-\mathrm{CH}_{3}$ and $-\mathrm{CH}_{2}-$ protons of new species 2. (C) Decomposition of $\mathbf{1}$. Spectral range: $0.5-3.5 \mathrm{ppm}$. due to the formation of the species 2 , but also to the thermal decomposition of the $\left[\mathrm{Cu}^{\mathrm{III}}{ }_{2}(\mu-\mathrm{O})_{2}\right]^{2+}$ core. New signals appeared, centered at $\delta 2.83(\mathrm{~d})$ and $1.08(\mathrm{t}) \mathrm{ppm}$ corresponding to the ligand's protons of the newly formed diamagnetic species 2 (Fig. 6(A)). It was possible to observe these signals at $233 \mathrm{~K}$, because the rate of reaction between 1 and $\mathrm{PPh}_{3}$ had increased sufficiently relative to that at $193 \mathrm{~K}$, with the concomitant increase in the concentration of the ( $\mu$-oxo)dicopper(II) species. The lack of any line broadening in these signals was consistent with the formation of a diamagnetic species $\mathbf{2}$, in accordance with Scheme 3.

In contrast, when a dichloromethane solution of $\mathrm{PPh}_{3}$ was added to 1 under anaerobic conditions, the intensity of the bis $(\mu-$ oxo)dicopper(III) complex remained practically unchanged. In addition, no signals were observed at $\delta 2.83$ and $1.08 \mathrm{ppm}$, even though some oxo-transfer from 1 to $\mathrm{PPh}_{3}$ had taken place under these conditions $\left(10 \%\right.$ converted to $\mathrm{O}=\mathrm{PPh}_{3}$; see Table 1$)$ upon warming the experimental solution to room temperature (Fig. 6(B)). The changes in the ${ }^{1} \mathrm{H}$ NMR spectra observed upon warming the experimental mixture containing 1 and $\mathrm{PPh}_{3}$ under Ar conditions were the same as that noted upon the decomposition of 1 (Fig. 6(C)). These observations are consistent with our earlier conclusion that the oxo-transfer reaction between the $\left[\mathrm{Cu}_{2}{ }_{2}(\mu-\mathrm{O})_{2}(\mathrm{~L})_{2}\right]^{2+}$ complex and $\mathrm{PPh}_{3}$ occurs principally in the presence of dioxygen, providing additional support for $\mathrm{O}_{2}$ as a catalyst for the oxygen-atom transfer reaction from 1 to $\mathrm{PPh}_{3}$, as we have already demonstrated in the kinetic studies described earlier.

\section{Decomposition of bis( $\mu$-oxo)dicopper(III) complex}

Reaction of 1 with $\mathrm{PPh}_{3}$ was accompanied by the process of complex degradation, involving oxidative ligand sidearm $\mathrm{N}$-dealkylation at sufficiently high temperatures. This process apparently proceeded through the monooxygenase reaction $^{33}$ (Scheme 8) similar to that reported previously by Tolman et al. ${ }^{33,41-43}$ Basically, N-dealkylation began at temperatures above $233 \mathrm{~K}$, since no products of complex degradation were found at temperature $\leq 233 \mathrm{~K}$ for reaction times as long as $10 \mathrm{~h}$. After work up, a mixture of intact ligand $N, N, N^{\prime}, N^{\prime}$-tetraethylethylenediamine (L) and $N, N, N^{\prime}$ triethylethylenediamine $\left(\mathrm{L}^{\prime}\right)$, the product of $\mathrm{N}$-dealkylation with the loss of one ethyl group, were identified by GC/GCMS analysis. When the decomposition of the 1 was followed under anaerobic conditions, the molar ratio of $\mathrm{L}: \mathrm{L}^{\prime}$ was found to be $3: 1$, in accordance with Scheme 8 . However, when the sample was incubated with $\mathrm{PPh}_{3}$ under aerobic conditions for $2 \mathrm{~h}$ and then gradually warmed to room temperature over a $3 \mathrm{~h}$ period, $\mathrm{L}: \mathrm{L}^{\prime}$ increased to $6: 1$, as expected because of the competing oxo-atom transfer to $\mathrm{PPh}_{3}$ at the lower temperatures. Acetaldehyde was identified as a co-product by GC, and ${ }^{1} \mathrm{H}$ NMR spectroscopy at 2.18 ppm (Fig. 6(C)).

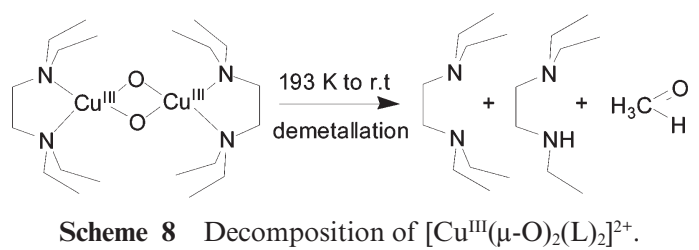

Interestingly, N-dealkylation chemistry did not occur in the presence of $10 \%$ of 2,2,6,6-tetramethyl-1-piperidinyloxy (TEMPO). According to GC analysis, the decomposed solution contained the intact ligand $N, N, N^{\prime}, N^{\prime}$-tetraethylethylenediamine and the TEMPO oxidation product 2,2,6,6-tetramethyl1-piperidine. Since TEMPO is well established as a Lewis base in d-block coordination chemistry and can bind to $\mathrm{Cu}$ (II) with the formation of $\mathrm{CuCl}_{2}$ (TEMPO) and $\mathrm{CuBr}_{2}$ (TEMPO) adducts, ${ }^{44}$ introduction of TEMPO into the solution of $\mathbf{1}$ may lead to association of the nitroxide radical to one of copper(III) atoms, 
and cause redistribution of the electron density in the $\mathrm{Cu}_{2} \mathrm{O}_{2}$ core and suppress the process of ligand $\mathrm{N}$-dealkylation.

\section{Summary}

In this study, we have followed the oxygen-atom transfer from 1 to $\mathrm{PPh}_{3}$ at $193 \mathrm{~K}$ and above. The reactivity of 1 toward $\mathrm{PPh}_{3}$, as well as the details of the oxo-transfer chemistry was found to be strongly dependent on the experimental conditions.

The bis( $\mu$-oxo)dicopper(III) complex was found to be surprisingly inert when an attempt was made to carry out the oxygen-atom transfer under anaerobic conditions in Ar. If the reaction was carried out under excess of dioxygen, it produced $\mathrm{O}=\mathrm{PPh}_{3}$ and a diamagnetic oxo-bridged dicopper(II) species $\mathbf{2}$ or the bis( $\mu$-hydroxo)dicopper(II) species 3. Isotope-labeling experiments established that the oxygen atom incorporated into the $\mathrm{O}=\mathrm{PPh}_{3}$ came either from the bis( $\mu$-oxo)dicopper(III) complex or from the exogenous dioxygen. The major labeled $\mathrm{O}=\mathrm{PPh}_{3}$ product contains the oxygen isotope derived from $\mathbf{1}$.

The reaction was shown to be catalytic, with $\mathrm{O}_{2}$ as the catalyst. However, it was stoichiometric with respect to the starting copper bis( $\mu$-oxo)dicopper(III) complex. Depending on the temperature, the reaction was complete when equilibrium had been reached with respect to the product $\mathrm{O}=\mathrm{PPh}_{3}$, or when the bis( $\mu$-oxo)dicopper(III) complex was completely transformed to the bis( $\mu$-hydroxo)dicopper(II) compound. At $193 \mathrm{~K}$ the reaction was slow and the equilibrium remained toward the reactant side, but as the temperature was increased, complete oxygenatom transfer was observed.

The relative inertness of the bis( $\mu$-oxo)dicopper(III) complex toward $\mathrm{PPh}_{3}$ under anaerobic conditions could be alleviated by reductive activation of the bis( $\mu$-oxo)dicopper(III) core to give the mixed valence $\left[\mathrm{Cu}^{\mathrm{II}} \mathrm{Cu}^{\mathrm{III}}(\mu-\mathrm{O})_{2}\right]^{+}$core. This reductive activation could be accomplished by preparing the bis $(\mu-$ oxo)dicopper(III) complex in the presence of excess $\mathrm{Cu}$ (I) starting precursor. The latter provided a source of reducing equivalents to convert the bis( $\mu$-oxo)dicopper(III) core in the complex to the more reactive mixed valence $\left[\mathrm{Cu}^{\mathrm{II}} \mathrm{Cu}^{\mathrm{III}}(\mu-\mathrm{O})_{2}\right]^{+}$core. Under these conditions, the $\mathrm{PPh}_{3}$ oxidation proceeded in a facile manner and resulted in the formation a highly symmetrical $\mathrm{Cu}$ (II) compound, presumably the triangular copper(II) cluster complex, with its characteristic isotropic copper EPR signal. Recently, Taki et al. reported that a mixed-valence bis( $\mu$-oxo) trinuclear copper(II,II,III) species could be assessed by the reaction of the copper(I) starting material with the bis( $\mu$-oxo)dicopper(III) complex. ${ }^{45}$ Earlier, the structure of the mixed-valence trinuclear copper(II,II,III) complex, was reported by Cole et al. ${ }^{46}$

At higher temperatures near ambient conditions, ligand degradation competed with the oxo-transfer reaction, and the $\mathrm{PPh}_{3}$ oxidation was accompanied by ligand side arm Ndealkylation of one of the ethyl groups.

The results of the present study extended the earlier work of Mahadevan and others, ${ }^{13,14}$ by providing greater insight into the intimate mechanistic details of the chemistry of the system. This advance was only possible by a detailed kinetic study of the system to ascertain the reaction mechanism, and by appealing to a number of physical methods, including X-ray absorption spectroscopy, UV-visible spectroscopy, EPR, NMR, and isotope labeling, to identify or rationalize the products as well as some of the intermediates formed during the time course of the reaction.

\section{Experimental}

\section{General procedures}

All chemical except the complexes, were obtained from commercial sources as a reagent grade quality and used as received unless noted otherwise. Acetonitrile (Merck, HPLC grade) and benzonitrile (Merk) used in the syntheses of the copper(I) complexes were distilled from $\mathrm{P}_{4} \mathrm{O}_{10}$ (Merck). $N, N, N^{\prime}, N^{\prime}$-tetraethylethylenediamine (L) was purchased from
Aldrich (98\%) and distilled in vacuo from $\mathrm{NaH}$ before use. Purity of the ligand $(99.9 \%)$ was controlled by GC analysis. Triphenylphosphine (Aldrich) and triphenylphosphine oxide (Merk) were purified and dried according to published procedures. ${ }^{47}$ Dichloromethane (Aldrich, 99.8\%, not stabilized) was stirred over concentrated $\mathrm{H}_{2} \mathrm{SO}_{4}$, washed with de-ionized water, followed by $\mathrm{Na}_{2} \mathrm{CO}_{3}$ (satd.) solution and again water, dried under anhydrous $\mathrm{MgSO}_{4}$ and finally distilled from $\mathrm{P}_{4} \mathrm{O}_{10}$ in the absence of light. For kinetics studies, dichloromethane (Merck, spectroscopy grade, $99.9 \%$, stabilized with 2-methyl-2-butene) was freshly distilled from $\mathrm{CaH}_{2}$. Diethyl ether (Mallinckrodt) was distilled from Na/benzophenone. Oxygen gas (99.8\%, Fong Ming), used for oxygenation, was dried by passing it through two short columns in succession of $\mathrm{P}_{4} \mathrm{O}_{10}$ and Drierite, followed by a cold trap $(193 \mathrm{~K}) \cdot{ }^{18} \mathrm{O}_{2}\left(95-98 \%\right.$ atom $\left.{ }^{18} \mathrm{O}\right)$ was obtained from Cambridge Isotope Laboratories Inc. and used without further purification. The extent of incorporation of ${ }^{18} \mathrm{O}$ into the products of the oxidation reaction was accomplished by GC-MS analysis. The air/moisture-sensitive materials were prepared and handled either in a Braun Company inert-atmosphere glove box under $\mathrm{N}_{2}$, where the samples for IR, NMR and UV-vis spectroscopy were also prepared, or by using standard Schlenk and vacuum line techniques. The solvent and solutions were deoxygenated either by three freeze-thaw vacuum/purge cycles with argon or by bubbling argon (20 $\mathrm{min})$ directly through the solutions. Saturated solutions of $\mathrm{O}_{2}$ and $\mathrm{Ar}$ in $\mathrm{CH}_{2} \mathrm{Cl}_{2}$ were prepared by bubbling the gas through the liquid for $20 \mathrm{~min}$ at room temperature and $30 \mathrm{~min}$ at low temperature. The solubility of $\mathrm{O}_{2}$ in dichloromethane was accepted to be $5.8 \mathrm{mM}$ at $293 \mathrm{~K}$ according to the literature. ${ }^{48,49}$ The changes in the reagent concentrations as well as dioxygen concentration in dilute dichloromethane with the change in temperature were calculated by using equations: $d_{T}=1.370(2)-0.00180(2) T\left(T\right.$ in $\left.{ }^{\circ} \mathrm{C}\right)$ and $C_{T}=C_{20}{ }^{\circ} \mathrm{C}\left(d_{T} / d_{20}{ }^{\circ} \mathrm{C}\right){ }^{49}$ Consequently the concentration of $\mathrm{O}_{2}$ in the saturated solution of dichloromethane at $193 \mathrm{~K}$ was calculated as $6.58 \mathrm{mM}$.

\section{Methods}

GC analysis was performed on a Hewlett-Packard 6890 series gas chromatograph, equipped with capillary injector and flame ionization detector using a 50-m HP-1 capillary column. GC-MS analysis was performed on Hewlett-Packard 6890 series gas chromatograph equipped with capillary injector and flame ionization detector, using a 60-m HP-5 capillary column interfaced with mass selected detector (MS) (HP5972). Infrared spectra were measured in a Nujol mull on a Perkin-Elmer 283 instrument. ${ }^{1} \mathrm{H}$ NMR spectra were recorded in $\mathrm{CDCl}_{3}, \mathrm{CD}_{2} \mathrm{Cl}_{2}$ and/or a mixture of $\mathrm{CD}_{2} \mathrm{Cl}_{2}-\mathrm{CH}_{2} \mathrm{Cl}_{2}$. (1:10) on a Bruker AMX-400 spectrometer. Chemical shifts (in ppm) are referenced either to an internal standard of $\mathrm{Me}_{4} \mathrm{Si}$, or to the residual solvent peak (dichloromethane) whose chemical shift was referred to $\mathrm{Me}_{4} \mathrm{Si}$ in the low-temperature experiments.

\section{EPR spectroscopy}

EPR spectra were recorded on a Bruker E-500 spectrometer, equipped with Bruker TE102 cavity. In the EPR experiments, sample temperature was maintained at $77 \mathrm{~K}$ by using a liquidnitrogen finger Dewar. The EPR samples were prepared by rapid transferring, through a cannula, the chilled experimental mixture $(193 \mathrm{~K})$ from the reaction flask to the EPR tube, equipped with a septum port, and immediately frozen in liquid nitrogen. The copper spin concentration was measured against copper perchlorate standard solutions $(7200,1440,288,58 \mu \mathrm{M})$ in $\mathrm{MeOH}-\mathrm{CH}_{2} \mathrm{Cl}_{2}(1: 5, \mathrm{v} / \mathrm{v})$. The EPR spectra of these copper standards were recorded at $77 \mathrm{~K}$ with microwave power $5 \mathrm{~mW}$. Upon performing baseline corrections, the spectra were double integrated from 2500 to $3500 \mathrm{G}$, and a standard curve, correlating the EPR intensity with copper concentration, was generated. The copper spin concentration measured for the various samples against the copper perchlorate standards were then inferred 
from the EPR signal intensity and the standard curve. The same samples, used in the EPR spin quantitation experiments, were subsequently analyzed by gas chromatography.

\section{X-Ray absorption spectroscopy}

X-Ray absorption spectroscopy data were collected at the National Synchrotron Radiation Research Center, (NSRRC) (beam line Wiggler 17C, Si (111) double crystal monochromator, $1.5 \mathrm{GeV}$, internal energy calibration) in Hsinchu (Taiwan). All samples for X-ray absorption spectroscopy experiments were loaded into a sample holder $(1.4 \mathrm{~cm} \times 1.4 \mathrm{~cm} \times 0.2 \mathrm{~cm})$ covered with sheets of Kapton. The samples were prepared by rapidly transferring, through a cannula (with application of a slight positive pressure of oxygen/argon), the cold experimental mixture $(193 \mathrm{~K})$ from the reaction flask to the sample holder, equipped with a septum port, and then rapidly frozen in liquid nitrogen. Samples were stored under liquid $\mathrm{N}_{2}$ until ready for use. During the measurements, the samples were kept at $77 \mathrm{~K}$ (liquid nitrogen). Fluorescence data were measured using an Ar-filled ionization chamber detector equipped with a $\mathrm{Ni}$ filter and Soller slits. Data represented an average of 10-16 scans. Data reduction included energy calibration assigning the first inflection point of the $\mathrm{Cu}$ foil to $8980.3 \mathrm{eV}$, pre-edge subtraction using a polynomial function, spline removal, and normalization. Spectra were recorded at two different run times and two separate preparations of $\mathbf{1}$ with and without $\mathrm{PPh}_{3}$.

\section{Kinetic measurements}

Time-resolved low-temperature absorption spectra were obtained by using a Hewlett-Packard 8453 diode array spectrometer equipped with custom-designed immersion fiber-optic quartz probe with $10 \mathrm{~mm}$ path length (Hellma, Inc.), fitted to the Schlenk vessel $\left(50 \mathrm{~cm}^{3}\right)$ with stopcock and vacuum inlet. The Schlenk vessel with experimental solution and with immersion fiber-optic probe was placed in a Dewar filled with acetone. To maintain and control low temperature, a copper-tubing coil was inserted into the acetone-filled Dewar through which cold methanol was circulated from an external source (Neslab cryocool system: CC-100 II Immersion Cooler, Agitainer, and Cryocontrol Temperature Controller). The temperature in the Dewar was controlled by an ACE Glass Model 8292 organicliquid filled thermometer $\left(-100\right.$ to $\left.50{ }^{\circ} \mathrm{C}\right)$. The temperature variation was within $\pm 1{ }^{\circ} \mathrm{C}$.

The kinetics of the reaction between 1 and $\mathrm{PPh}_{3}$ were studied in dichloromethane at $193 \mathrm{~K}$ by following the time dependence of the absorbance at $404 \mathrm{~nm}$ due to 1 . A starting solution of complex 1 was prepared in situ by the reaction of $[\mathrm{LCu}(\mathrm{MeCN})] \mathrm{BF}_{4}$ precursor and dry oxygen gas (see preparation) in the reaction vessel equipped with the fiber-optic quartz probe and a stir bar. Typically a small volume of concentrated dichloromethane solution of $[\mathrm{LCu}(\mathrm{MeCN})] \mathrm{BF}_{4}$ was injected into $40-50 \mathrm{~cm}^{3}$ of the dry, deoxygenated dichloromethane (placed in the reaction flask), followed by bubbling precooled oxygen gas through this solution for $20 \mathrm{~min}$ to accomplish the formation of the bis( $\mu$-oxo)dicopper(III) complex at $193 \mathrm{~K}$. The concentration of $[\mathrm{LCu}(\mathrm{MeCN})] \mathrm{BF}_{4}$ precursor used in the kinetic experiments was in the range $0.8-1.1 \mathrm{mM}$. Before the $[\mathrm{LCu}(\mathrm{MeCN})] \mathrm{BF}_{4}$ was transferred into the flask with the UV-Vis probe, a background scan with pure solvent was taken. After formation of the bis( $\mu$-oxo)dicopper(III) complex, a small volume $\left(0.5 \mathrm{~cm}^{3}\right)$ of concentrated solution of the triphenylphosphine in $\mathrm{CH}_{2} \mathrm{Cl}_{2}$ was introduced by a cannula, and the rate of the reaction was then followed.

For anaerobic conditions $\mathrm{O}_{2}$ was removed by gently bubbling Ar gas into the solution of the 1 for $30 \mathrm{~min}$. During the bubbling of Ar gas no spectral change of the bis $(\mu-$ oxo)dicopper(III) complex was observed at this temperature. To vary the concentration of dioxygen in the reaction of $\mathbf{1}$ with $\mathrm{PPh}_{3}$, calibrated volumes of dichloromethane, saturated with $\mathrm{Ar}$ or $\mathrm{O}_{2}$, were added to the previously degassed solution of bis( $\mu$-oxo)dicopper(III) complex by using Hamilton airtight syringes. Each kinetic run was repeated three times. The relative standard errors of the single $k_{\text {obs }}$ was $\sim 5 \%$ and for the average values $\sim 10 \%$. The analysis of the raw kinetic data was performed by using Origin 6.0 Professional Microcal Software.

\section{Preparations}

$\left[\mathrm{Cu}(\mathrm{PhCN})_{4}\right] \mathrm{ClO}_{4}$ and $\left[\mathrm{Cu}(\mathrm{MeCN})_{4}\right] \mathrm{BF}_{4}$ were prepared according to literature methods. ${ }^{50,51}$ The complexes $[\mathrm{LCu}(\mathrm{PhCN})] \mathrm{ClO}_{4}$ and $[\mathrm{LCu}(\mathrm{MeCN})] \mathrm{BF}_{4}$ were prepared as described previously. ${ }^{14}$ Equimolar amounts of $\left[\mathrm{Cu}(\mathrm{PhCN})_{4}\right] \mathrm{ClO}_{4}$ or $\left[\mathrm{Cu}(\mathrm{MeCN})_{4}\right] \mathrm{BF}_{4}$ and $N, N, N^{\prime}, N^{\prime}$-tetraethylethylenediamine (L) were combined in $\mathrm{CH}_{2} \mathrm{Cl}_{2}$ in a volumetric flask in the dry box to yield colorless solutions of $[\mathrm{LCu}(\mathrm{PhCN})] \mathrm{ClO}_{4}$ or $[\mathrm{LCu}(\mathrm{MeCN})] \mathrm{BF}_{4}$, respectively, of known concentrations that were varied over the range 0.08-8.7 mM. [LCu(PhCN)]ClO ${ }_{4}:{ }^{1} \mathrm{H}$ NMR $\left(\mathrm{CD}_{2} \mathrm{Cl}_{2}, 298 \mathrm{~K}\right)$ : $\delta 1.29\left(12 \mathrm{H}, \mathrm{t}, 4 \mathrm{CH}_{3}\right), 2.73\left(4 \mathrm{H}, \mathrm{s}, 2 \mathrm{CH}_{2}\right), 2.82\left(8 \mathrm{H}, \mathrm{q}, 4 \mathrm{CH}_{2}\right)$, $7.5\left(\mathrm{~m}, \mathrm{C}_{6} \mathrm{H}_{5}\right), 7.7\left(\mathrm{~m}, \mathrm{C}_{6} \mathrm{H}_{5}\right) .{ }^{1} \mathrm{H}$ NMR $\left(\mathrm{CD}_{2} \mathrm{Cl}_{2}, 193 \mathrm{~K}\right): \delta 1.19$ $\left(12 \mathrm{H}, \mathrm{s}, 4 \mathrm{CH}_{3}\right), 2.7-2.9\left(12 \mathrm{H}, \mathrm{m}, 6 \mathrm{CH}_{2}\right) .7 .6\left(\mathrm{~m}, \mathrm{C}_{6} \mathrm{H}_{5}\right), 7.7(\mathrm{~m}$, $\mathrm{C}_{6} \mathrm{H}_{5}$ ). The solutions of $\mathrm{Cu}(\mathrm{I})$ precursor were prepared freshly as needed and used immediately.

CAUTION: Perchlorate salts of the metal complexes with organic ligands are potentially explosive and should be handled with care and in small quantities.

$\left[\mathrm{Cu}_{2}^{\mathrm{III}}{ }_{2}(\mu-\mathrm{O})_{2}(\mathrm{~L})_{2}\right](\mathrm{X})_{2} \quad\left(\mathrm{X}=\mathrm{ClO}_{4}^{-}, \quad \mathrm{BF}_{4}^{-}\right) \quad$ (1). $\quad$ Bis $(\mu$-oxo $)-$ dicopper(III) complex $\mathbf{1}$ was generated in situ as described previously ${ }^{14}$ by the reaction of $[\mathrm{LCu}(\mathrm{PhCN})] \mathrm{ClO}_{4}$ or $[\mathrm{LCu}-$ $(\mathrm{MeCN}) \mathrm{BF}_{4}$ precursor and dry oxygen in highly purified dry $\mathrm{CH}_{2} \mathrm{Cl}_{2}$ by bubbling $\mathrm{O}_{2}$ gas through the solution for $\sim 5-20 \mathrm{~min}$ with stirring. The concentrations of $\mathrm{Cu}(\mathrm{I})$ precursor used were in the range $0.08-8.7 \mathrm{mM}$. The initially colorless solution became yellow-brown or deep brown depending on the concentration of the starting $\mathrm{Cu}(\mathrm{I})$ complex. Spectroscopic characterizations of 1 were performed in $\mathrm{CH}_{2} \mathrm{Cl}_{2}$ at $193 \mathrm{~K}$. EPR $(9.517 \mathrm{GHz}$, $77 \mathrm{~K})$ : silent; UV-Vis, $\lambda_{\max } / \mathrm{nm}\left(\varepsilon / \mathrm{M}^{-1} \mathrm{~cm}^{-1}\right): 307$ (17000), 404 (24000). Cu K-edge spectrum ( $4.3 \mathrm{mM}, 77 \mathrm{~K}$ ) revealed a transition at $8981.1 \pm 0.5 \mathrm{eV}$ (data from three separate preparations). ${ }^{1} \mathrm{H}$ NMR $\left(\mathrm{CD}_{2} \mathrm{Cl}_{2}\right): \delta 1.4\left(12 \mathrm{H}, \mathrm{t}, 4 \mathrm{CH}_{3}\right), 2.99-3.28(12 \mathrm{H}, \mathrm{m}$, $6 \mathrm{CH}_{2}$ ).

$\left[\mathrm{Cu}_{2}{ }_{2}(\mu-\mathrm{OH})_{2}(\mathrm{~L})_{2}\right]\left(\mathrm{ClO}_{4}\right)_{2} \cdot \mathrm{H}_{2} \mathrm{O}$ (3). A yellow-brown solution of $1(1 \mathrm{mM})$ in $\mathrm{CH}_{2} \mathrm{Cl}_{2}$ at $193 \mathrm{~K}$ was prepared as described above $\left(0.10 \mathrm{~g}, 0.174 \mathrm{mmol}\right.$ of $\left[\mathrm{Cu}(\mathrm{PhCN})_{4}\right] \mathrm{ClO}_{4}$ precursor $)$. When the solution of $\mathbf{1}$ in $\mathrm{CH}_{2} \mathrm{Cl}_{2}$ was allowed to warm to room temperature, a blue solution resulted. Addition of an equal volume of the $\mathrm{Et}_{2} \mathrm{O}$ yielded a blue precipitate, which was recrystallized from $\mathrm{CH}_{2} \mathrm{Cl}_{2}-\mathrm{Et}_{2} \mathrm{O}(1: 3)$, washed with $\mathrm{Et}_{2} \mathrm{O}$ and vacuum-dried $(0.037 \mathrm{~g}, 59 \%)$. Anal. Calc. for $\mathrm{C}_{20} \mathrm{H}_{52} \mathrm{Cl}_{2} \mathrm{Cu}_{2} \mathrm{~N}_{4} \mathrm{O}_{11}$ : C, 33.24; H, 7.2; N, 7.75\%. Found: C, 33.39; H, 7.37; N, 7.53\%. IR (Nujol), $v_{\max } / \mathrm{cm}^{-1}: 3518(\mu-\mathrm{OH}), 3423\left(\mathrm{H}_{2} \mathrm{O}\right), 1088\left(\mathrm{ClO}_{4}^{-}\right)$, $627\left(\mathrm{ClO}_{4}^{-}\right)$. UV-Vis $\left(\mathrm{CH}_{2} \mathrm{Cl}_{2}\right): \lambda_{\max } / \mathrm{nm}\left(\varepsilon / \mathrm{M}^{-1} \mathrm{~cm}^{-1}\right): 560$ (260), 361 (1500).

\section{Reaction of $\left[\mathrm{Cu}_{2}{ }_{2}(\mu-\mathrm{O})_{2}(\mathrm{~L})_{2}\right]\left(\mathrm{ClO}_{4}\right)_{2}$ with $\mathrm{PPh}_{3}$}

The starting complex $\left[\mathrm{LCu}(\mathrm{PhCN}) \mathrm{ClO}_{4}\right.$ was prepared by combining $\left[\mathrm{Cu}(\mathrm{PhCN})_{4}\right] \mathrm{ClO}_{4} \quad(34 \quad \mathrm{mg}, \quad 0.06 \mathrm{mmol})$ and $N, N, N^{\prime}, N^{\prime}$-tetraethylethylenediamine $\left(0.01279 \mathrm{~cm}^{3}\right.$, $0.06 \mathrm{mmol})$ in $\mathrm{CH}_{2} \mathrm{Cl}_{2}\left(25 \mathrm{~cm}^{3}\right)$ in the glove box. A solution of 1 was generated from $[\mathrm{LCu}(\mathrm{PhCN})] \mathrm{ClO}_{4}(0.06 \mathrm{mmol})$ and excess dioxygen as mentioned above. Then, 2 equiv. (with respect to complex 1) of precooled solution of $\mathrm{PPh}_{3}(15.7 \mathrm{mg}$, $0.06 \mathrm{mmol})$ in $\mathrm{CH}_{2} \mathrm{Cl}_{2}\left(2 \mathrm{~cm}^{3}\right)$ was introduced by cannulation and the mixture was stirred at $193 \mathrm{~K}$. To monitor the products of the reaction with time at $193 \mathrm{~K}$, aliquots were taken using a cannula, quenched at low temperature with $7 \mathrm{M}$ ammonia in $\mathrm{CH}_{3} \mathrm{OH}$, then $32 \%$ ammonia, followed by repetitive extraction with $\mathrm{CH}_{2} \mathrm{Cl}_{2}$. The combined organic layers were dried over 
$\mathrm{MgSO}_{4}$, filtrated and were subjected to GC/GC-MS analysis. The conversion of $\mathrm{PPh}_{3}$ into $\mathrm{O}=\mathrm{PPh}_{3}$ was calculated on the basis of the signals area in the $\mathrm{GC}$ chromatograms $\left(\mathrm{O}=\mathrm{PPh}_{3}\right)$ $\mathrm{PPh}_{3}$ ) by using the internal standard method. trans-Stilbene oxide was used as the internal standard. Mass recovery of the products was $\geq 90 \%$. GC data were obtained using the following conditions: $\left[150{ }^{\circ} \mathrm{C}(1 \mathrm{~min})\right.$ at $40^{\circ} \mathrm{C} \mathrm{m^{-1 }}$ to $250{ }^{\circ} \mathrm{C}$ (10 min)], $t_{\mathrm{R}} / \mathrm{min}, \mathrm{PPh}_{3}: 8.36 ; \mathrm{O}=\mathrm{PPh}_{3}: 11$. GC-MS data were obtained under conditions: $\left[150{ }^{\circ} \mathrm{C}(1 \mathrm{~min})\right.$ at $20^{\circ} \mathrm{C} \mathrm{m^{-1 }}$ to $\left.250{ }^{\circ} \mathrm{C}(16 \mathrm{~min})\right], t_{\mathrm{R}} / \mathrm{min},(\mathrm{m} / \mathrm{z}), \mathrm{PPh}_{3}: 13.2\left(262, \mathrm{M}^{+}\right) ; \mathrm{O}=\mathrm{PPh}_{3}$ : $21.7\left(278, \mathrm{M}^{+}\right) ;{ }^{18} \mathrm{O}=\mathrm{PPh}_{3}: 21.7\left(280, \mathrm{M}^{+}\right)$.

\section{Oxidative N-dealkylation reaction}

Ligand isolation. A solution $\left(25 \mathrm{~cm}^{3}\right)$ of bis( $\mu$-oxo)dicopper(III) complex 1 (0.03 mmol) was prepared as described above. 2 equivalents of $\mathrm{PPh}_{3}(0.06 \mathrm{mmol})$ in $\mathrm{CH}_{2} \mathrm{Cl}_{2}\left(2 \mathrm{~cm}^{3}\right)$ were added and the mixture was stirred at $193 \mathrm{~K}$ for $2 \mathrm{~h}$. For anaerobic conditions, excess $\mathrm{O}_{2}$ was removed by gently bubbling Ar through the solution for $15 \mathrm{~min}$ at $193 \mathrm{~K}$. When this solution was allowed to slowly warm and incubate for overnight at room temperature under positive dioxygen, or argon pressure, respectively, a blue or green solution was obtained. A solution $\left(10 \mathrm{~cm}^{3}\right)$ of concentrated $(30 \%)$ ammonia was added and the mixture was stirred vigorously giving blue aqueous and light yellow $\mathrm{CH}_{2} \mathrm{Cl}_{2}$ layers. The aqueous layer was separated and further extracted with $\mathrm{CH}_{2} \mathrm{Cl}_{2}\left(3 \times 5 \mathrm{~cm}^{3}\right)$. The combined organic layers were dried over $\mathrm{MgSO}_{4}$ and solvent was removed in vacuo giving an oily yellow mixture of products ( $\mathrm{L}$ and $\left.\mathrm{L}^{\prime}\right)$. These products were subsequently characterized by GC/GC-MS and ${ }^{1} \mathrm{H}$ NMR spectroscopy and compared with authentic compounds. ${ }^{1} \mathrm{H}$ NMR $\left(\mathrm{CDCl}_{3}\right), \mathrm{L}^{\prime}: \delta 1.01\left(6 \mathrm{H}, \mathrm{t}, 2 \mathrm{CH}_{3}\right), 1.11(3 \mathrm{H}$, t, $\left.\mathrm{CH}_{3}\right), 2.49-2.57\left(6 \mathrm{H}, \mathrm{m}, 3 \mathrm{CH}_{2}\right), 2.63-2.68\left(4 \mathrm{H}, \mathrm{m}, 2 \mathrm{CH}_{2}\right)$; L: $\delta 1.04\left(12 \mathrm{H}, \mathrm{t}, 4 \mathrm{CH}_{3}\right), 2.49-2.52\left(12 \mathrm{H}, \mathrm{m}, 6 \mathrm{CH}_{2}\right) . \mathrm{GC}, t_{\mathrm{R}} / \mathrm{min}$, $\mathrm{L}^{\prime}$ : 8.42 ; L: 9.52 under conditions: $\left[70^{\circ} \mathrm{C}(1 \mathrm{~min})\right.$ at $20 \mathrm{C}^{\circ} \mathrm{min}^{-1}$ to $\left.200^{\circ} \mathrm{C}(10 \mathrm{~min})\right]$. GC-MS, $t_{\mathrm{R}} / \mathrm{min}(\mathrm{m} / \mathrm{z}), \mathrm{L}^{\prime}: 22.2\left(144, \mathrm{M}^{+}\right)$, L: $24.96\left(172, \mathrm{M}^{+}\right)$under conditions: $\left[33^{\circ} \mathrm{C}(5 \mathrm{~min})\right.$ at $6{ }^{\circ} \mathrm{C} \mathrm{min}-1$ to $\left.200^{\circ} \mathrm{C}(5 \mathrm{~min})\right]$.

Identification of acetaldehyde from the decomposition of $\left[\mathrm{Cu}_{2}{ }_{2}(\mu-\mathrm{O})_{2}(\mathrm{~L})_{2}\right]\left(\mathrm{ClO}_{4}\right)_{2}$. A small amount $\left(0.5 \mathrm{~cm}^{3}\right)$ of the blue solution resulting from the decomposition of complex 1 under anaerobic conditions was removed from the reaction vessel and was passed through a short column with neutral activated alumina. The column was washed with $\mathrm{CH}_{2} \mathrm{Cl}_{2}$ $\left(2 \times 1 \mathrm{~cm}^{3}\right)$. Copper compounds were retained on the column while the organic products eluted. Acetaldehyde was identified from the resultant solution by GC-MS analysis by comparison of its mass spectra and retention time to an authentic sample. GC-MS, $t_{\mathrm{R}} / \mathrm{min}(\mathrm{m} / \mathrm{z}): 4.55\left(44, \mathrm{M}^{+}\right)$, at conditions $\left[32^{\circ} \mathrm{C}(7 \mathrm{~min})\right.$ at $10{ }^{\circ} \mathrm{C} \mathrm{min}^{-1}$ to $\left.200{ }^{\circ} \mathrm{C}(5 \mathrm{~min})\right]$.

\section{Crystal structure determination of $\left[\mathrm{Cu}_{2}{ }_{2}(\mu-\mathrm{OH})_{2}(\mathrm{~L})_{2}\right]\left(\mathrm{ClO}_{4}\right)_{2}$}

Diffraction measurements were made on an Enraf-Nonius CAD-4 diffractometer by use of graphite-monochromatized Mo-K $\alpha$ radiation $(\lambda=0.7107 \AA)$. Unit cell parameters were obtained by a least-squares fit to the automatically centered settings for 25 reflections. Intensity data collected by use of $\omega-2 \theta$ scan mode. All intensity data were collected for Lorentz polarization and absorption (empirical $\psi$ corrections).

Crystal data. $\mathrm{C}_{20} \mathrm{H}_{50} \mathrm{Cl}_{2} \mathrm{Cu}_{2} \mathrm{~N}_{4} \mathrm{O}_{10}, M=704.62$, monoclinic, space group $P 2_{1} / c$ (no. 14), $a=7.6177(10), b=17.850(3)$, $c=13.9471(17) \quad \AA, \quad \beta=122.147(12)^{\circ}, \quad U=1605.7(4) \quad \AA^{3}$, $T=298(2) \mathrm{K}, Z=2, \mu(\mathrm{Mo}-\mathrm{K} \alpha)=1.542 \mathrm{~mm}^{-1}, 3036$ reflection measured, 2814 unique $\left(R_{\text {int }}=0.0220\right)$ which were used in all calculations. The final $w R\left(F^{2}\right)$ was 0.1084 (all data).

CCDC reference number 245728.

See http://www.rsc.org/suppdata/dt/b4/b406692h/ for crystallographic data in CIF or other electronic format.

\section{Acknowledgements}

This work was supported by Academia Sinica and by grants from the National Science Council (NSC 90-2113-M-001006, 90-2113-M-001-080 and 91-2113-M-006-006). We are grateful to Dr Jyh-Fu Lee of the Research Division of the National Synchrotron Radiation Research Center (NSRRC), Hsinchu, Taiwan for his kind assistance in the X-ray absorption measurements. We thank Mr Yuh-Sheng Wen for solving the X-ray structure of $\left[\mathrm{Cu}^{\mathrm{II}}{ }_{2}(\mu-\mathrm{OH})_{2}(\mathrm{~L})_{2}\right]\left(\mathrm{ClO}_{4}\right)_{2}$. We also thank Prof. J. F. Biellmann for helpful discussions.

\section{References}

1 J. P. Klinman, Chem. Rev., 1996, 96, 2541-2561.

2 E. I. Solomon, P. Chen, M. Metz, S.-K. Lee and A. E. Palmer, Angew. Chem., Int. Ed., 2001, 40, 4570-4590.

3 Bioinorganic Chemistry of Copper, ed. K. D. Karlin and Z. Tyeklár, Chapman \& Hall, New York, 1993.

4 M.-A. Kopf and K. D. Karlin, in Biomimetic Oxidations Catalyzed by Transition Metal Complexes, ed. B. Meunier, Imperial College Press, London, 2000, pp. 309-362.

5 A. G. Blackman and W. B. Tolman, Struct. Bonding (Berlin), 2000, 97, 179-211.

6 S. Schindler, Eur. J. Inorg. Chem., 2000, 2311-2326.

7 P. Gamez, P. G. Aubel, W. L. Driessen and J. Reedijk, Chem. Soc. Rev., 2001, 30, 376-385.

8 S. Itoh and S. Fukuzumi, Bull. Chem. Soc. Jpn., 2002, 75, 20812095.

9 I. Blain, M. Giorgi, I. De Riggi and M. Réglier, Eur. J. Inorg. Chem., 2001, 205-211.

10 T. D. P. Stack, Dalton Trans., 2003, 1881-1889.

11 N. Kitajima and Y. Moro-oka, Chem. Rev., 1994, 94, 737-757.

12 L. M. Mirica, X. Ottenwaelder and T. D. P. Stack, Chem. Rev., 2004, 104, 1013-1045; E. A. Lewis and W. B. Tolman, Chem. Rev., 2004, 104, 1047-1076, and references therein.

13 V. Mahadevan, J. L. DuBois, B. Hedman, K. O. Hodgson and T. D. P. Stack, J. Am. Chem. Soc., 1999, 121, 5583-5584.

14 V. Mahadevan, M. J. Henson, E. I. Solomon and T. D. P. Stack, J. Am. Chem. Soc., 2000, 122, 10249-10250.

15 L. M. Mirica, M. Vance, D. J. Rudd, B. Hedman, K. O. Hodgson, E. I. Solomon and T. D. P. Stack, J. Am. Chem. Soc., 2002, 124, 9332-9233.

16 P. P. Paul, Z. Tyeklár, R. R. Jacobson and K. D. Karlin, J. Am. Chem. Soc., 1991, 113, 5322-5332.

17 H. Hayashi, S. Fujinami, S. Nagatomo, S. Ogo, M. Suzuki, A. Uehara, Y. Watanabe and T. Kitagawa, J. Am. Chem. Soc., 2000, 122, 2124-2125.

18 M. Taki, S. Itoh and S. Fukuzumi, J. Am. Chem. Soc., 2002, 124, 998-1002.

19 C. X. Zhang, H.-C. Liang, E.-i. Kim, Q.-F. Gan, Z. Tyeklár, K.-C. Lam, A. L. Rheingold, S. Kaderli, A. D. Zuberbühler and K. D. Karlin, Chem. Commun., 2001, 631-632.

20 C. X. Zhang, H.-C. Liang, E.-i. Kim, J. Shearer, M. E. Helton, E. Kim, S. Kaderli, C. D. Incarvito, A. D. Zuberbühler, A. L. Rheingold and K. D. Karlin, J. Am. Chem. Soc., 2003, 125, 634 635 .

21 J. L. DuBois, P. Mukherjee, A. M. Collier, J. M. Mayer, E. I. Solomon, B. Hedman, T. D. P. Stack and K. O. Hodgson, J. Am. Chem. Soc., 1997, 119, 8578-8579.

22 M. J. Henson, P. Mukherjee, D. E. Root, T. D. P. Stack and E. I. Solomon, J. Am. Chem. Soc., 1999, 121, 10332-10345.

23 J. L. DuBois, P. Mukherjee, T. D. P. Stack, B. Hedman, E. I. Solomon and K. O. Hodgson, J. Am. Chem. Soc., 2000, 122, 5775-5787.

24 L.-S. Kau, D. J. Spira-Solomon, J. E. Penner-Hahn, K. O. Hodgson and E. I. Solomon, J. Am. Chem. Soc., 1987, 109, 6433-6442.

25 C. Lapinte, H. Riviere and A. Roselli, J. Chem. Soc., Chem. Commun., 1981, 1109-1110.

26 G. Davies and M. A. El-Sayed, Inorg. Chem., 1983, 22, 1257-1266.

27 N. Kitajima, T. Koda and Y. Moro-oka, Chem. Lett., 1988, 347-350.

28 K. D. Karlin, Y. Gultneh, J. C. Hayes and J. Zubieta, Inorg. Chem., 1984, 23, 519-521.

29 N. Kitajima, T. Koda, S. Hashimoto, T. Kitagawa and Y. Moro-oka, J. Am. Chem. Soc., 1991, 113, 5664-5671.

30 H. V. Obias, Y. Lin, N. N. Murty, E. Pidcock, E. I. Solomon, M. Ralle, N. J. Blackburn, Y.-M. Neuhold, A. D. Zuberbühler and K. D. Karlin, J. Am. Chem. Soc., 1998, 120, 12960-12961.

31 I. Sanyal, M. Mahroof-Tahir, M. S. Nasir, P. Ghosh, B. I. Cohen, Y. Gultneh, R. W. Cruse, A. Farooq, K. D. Karlin, S. Liu and J. Zubieta, Inorg. Chem., 1992, 31, 4322-4332. 
32 E. D. Estes, W. E. Hatfield and D. J. Hodgson, Inorg. Chem., 1974, 13, 1654-1657; M. Kodera, T. Kawata, K. Kano, Y. Tachi, S. Itoh and S. Kojo, Bull. Chem. Soc. Jpn., 2003, 76, 1957-1964.

33 S. Mahapatra, J. A. Halfen, E. C. Wilkinson, G. Pan, X. Wang, V. G. Young, Jr., C. J. Cramer, L. Que, Jr. and W. B. Tolman, J. Am. Chem. Soc., 1996, 118, 11555-11574.

34 B. J. Hathaway, in Comprehensive Coordination Chemistry, ed. G. Wilkinson, Pergamon, New York, 1987, vol. 5, ch. 53, pp. 662 674.

35 K. H.-C. Chen, C.-L. Chen, C.-F. Tseng, S. S.-F. Yu, S.-C. Ke, J.-F. Lee, H.-H. T. Nguyen, S. J. Elliott, J. O. Alben and S. I. Chan, J. Chin. Chem. Soc., 2004, 51, in press.

36 M. Kodera, Y. Tachi, T. Kita, H. Kobushi, Y. Sumi, K. Kano, M. Shiro, M. Koikawa, T. Tokii, M. Ohba and H. Okawa, Inorg. Chem., 2000, 39, 226-234.

37 S. Ferrer, F. Lloret, I. Bertomeu, G. Alzuet, J. Borrás, S. GarcíaGranda, M. Liu-González and J. G. Haasnoot, Inorg. Chem., 2002, 41, 5821-5830; J. Sanmartín, M. R. Bermejo, A. M. García-Deibe, O. R. Nascimento, L. Lezama and T. Rojo, J. Chem. Soc., Dalton Trans., 2002, 1030-1035.

38 S. J. Elliott, M. Zhu, L. Tso, H.-H. T. Nguyen, J. H.-K. Yip and S. I. Chan, J. Am. Chem. Soc., 1997, 119, 9949-9955; S. I. Chan, K. H.-C. Chen, S. S.-S. Yu, C.-L. Chen and S. S.-J. Kuo, Biochemistry, 2004, 43, 4421-4430.

39 M. Taki, S. Itoh and S. Fukuzumi, J. Am. Chem. Soc., 2001, 123 , 6203-6204.
40 V. H. Crawford, H. W. Richardson, J. R. Wasson, D. J. Hodgson and W. E. Hatfield, Inorg. Chem., 1976, 15, 2107-2110.

41 S. Mahapatra, S. Kaderli, A. Llobet, Y.-M. Neuhold, T. Palanché, J. A. Halfen, V. G. Young, Jr., T. A. Kaden, L. Que, Jr., A. D. Zuberbühler and W. B. Tolman, Inorg. Chem., 1997, 36, 63436356.

42 S. Mahapatra, J. A. Halfen and W. B. Tolman, J. Am. Chem. Soc., 1996, 118, 11575-11586.

43 S. Itoh, M. Taki, H. Nakao, P. L. Holland, W. B. Tolman, L. Que, Jr and S. Fukuzumi, Angew. Chem., Int. Ed., 2000, 39, 398-400.

44 J. Laugier, J.-M. Latour, A. Caneschi and P. Rey, Inorg. Chem., 1991, 30, 4474-4477.

45 M. Taki, S. Teramae, S. Nagatomo, Y. Tachi, T. Kitagawa, S. Itoh and S. Fukuzumi, J. Am. Chem. Soc., 2002, 124, 6367-6377.

46 A. P. Cole, D. E. Root, P. Mukherjee, E. I. Solomon and T. D. P. Stack, Science, 1996, 273, 1848-1850.

47 D. D. Perrin and W. L. F. Armarego, Purification of Laboratory Chemicals, Pergamon Press, New York, 1988.

48 R. Battino, in Oxygen and Ozone, ed. R. Battino, Pergamon Press, New York, 1981, vol. 7.

49 S. V. Kryatov, E. V. Rybak-Akimova, V. L. MacMurdo and L. Que, Jr., Inorg. Chem., 2001, 40, 2220-2228.

50 G. J. Kubas, B. Monzyk and A. L. Crumbliss, Inorg. Synth., 1979 , 19, 90-92.

51 D. S. Gill, L. Rodehüser, P. Rubini and J.-J. Delpuech, J. Chem. Soc., Faraday Trans., 1995, 91, 2307-2312. 